\title{
РЕГИОНАЛЬНАЯ ПОЛИТИЧЕСКАЯ ЭЛИТА: БАССЕЙН РЕКРУТИРОВАНИЯ И КАРЬЕРА
}

\author{
А.С. Быстрова, А.Б. Даугавет, А.В. Дука ${ }^{1}$, \\ Н.В. Колесник, А.В. Невский, Д.Б. Тев
}

\section{Соииологический институт РАН - филиал ФНИСЦ РАН, Санкт-Петербург, Россия}

Цитирование: Быстрова А.С., Даугавет А.Б., Дука А.В., Колесник Н.В., Невский А.В., Тев Д.Б. Региональная политическая элита: бассейн рекрутирования и карьера // Власть и элиты. 2020. Т. 7, № 1. С. 76-122.

DOI: https://doi.org/10.31119/pe.2020.7.1.4

Аннотация. Представлен анализ бассейна рекрутирования и карьерных путей региональных политиков. Эмпирическая основа исследования биографическая база данных политической элиты десяти субъектов РФ (к ней были отнесены депутаты региональных легислатур, а также депутаты ГД и члены СФ, представляюшие регионы). Исследование проведено с использованием структурно-биограбического метода, в рамках которого структура региональных элитных групп изучается в связи с биограбией персон, входящих в эти группы. В результате был выявлен ряд тендениий рекрутирования политической элиты. Исследование показало, что существенное меньшинство регионального депутатского корпуса укоренено в советской номенклатуре. Также некоторые политики имеют опыт службы в силовых структурах. Заметна тенденция профессионализаиии депутатского корпуса, которая, однако, сильно сдерживается тем фактом, что большинство законодателей работает на непостоянной основе. Выражена бюрократизация состава региональных легислатур, особенно их руководящего слоя, в котором много выходиев из административных органов, прежде всего регионального уровня. Одной из важнейших тенденицй рекрутирования политической элиты является плутократизаиия, т.е. приток представителей бизнеса в легислатуры. Депутатский корпус отличает высокая степень социальной закрытости: в нем доминируют выходиы из "руководящей страть»", почти нет персон, занимавиих "рабоче-крестьянские» позииии в постсоветский период, и слабо представлены выходиы из средних, промежуточных соииально-профессиональных категорий.

${ }^{1}$ Автор для связи. E-mail: alexander-duka@yandex.ru. 
Ключевые слова: региональные политические элиты, депутаты, политики, рекрутирование, карьерь, биографии, плутократизация, бюрократизация, бассейн рекрутирования.

\section{ЗНАЧИМОСТЬ ПРЕДМЕТА ИССЛЕДОВАНИЯ}

Значимость исследования социально-профессионального бассейна рекрутирования и карьеры региональной политической элиты обусловливается несколькими причинами. Во-первых, эти характеристики могут служить важным показателем структуры социальной и политической власти, которая лежит в основе элитного рекрутирования, особенностей общественно-политической системы, в рамках которой элита формируется и функционирует [Putnam 1976: 43; Matthews 1954: 5]. В этом смысле изучение источников рекрутирования и карьеры регионального депутатского корпуса позволяет, в частности, лучше понять особенности социально-экономической и политической организации данного региона и ее исторической эволюции. Речь может идти о характере взаимоотношений законодательной и исполнительной властей, особенностях отношений между бизнесом и публичной властью и соотношении экономических и политических сил в деловом сообществе субъекта РФ. Социально-профессиональный состав региональной легислатуры может быть своего рода «зеркалом», в котором отражается структура власти регионального сообщества.

Во-вторых, социально-профессиональное происхождение законодателей и особенности их карьеры могут в определенной степени влиять на их политические аттитюды и поведение. Впрочем, выводы исследований на этот счет неоднозначны [Edinger, Searing 1967; Derge 1959: 431; Dyer 1976: 452; Green et al. 1973; Matthews 1984: 555; Norris, Lovenduski 1995: 210; Региональные элиты 2001; Bianco 2005; Witko, Friedman 2008; Сафронов 2010; Carnes 2012; Chaisty 2013: 729-732; Carnes, Lupu 2015; Szakonyi 2017; Hansen, Carnes, Gray 2019]. Однако в целом, как отмечают Г. Кербо и Л. Фэйв, «хотя соответствие между происхождением, с одной стороны, и аттитюдами, ценностями и поведением - с другой, далеко от абсолютного, исследования показали достаточно сильные корреляции, для того чтобы сделать стоящим это направление исследования» [Kerbo, Fave 1979: 6]. Эта зависимость актуализирует изучение социально-профессиональных источников рекрутирования и особенностей карьеры элитных персон, включая депу- 
татов законодательных собраний субъектов РФ. Причем по отношению к этому сегменту элиты актуальность исследования указанных характеристик особенно велика, поскольку их влияние на законодательное поведение может усиливаться тем фактом, что большинство региональных депутатов работают на непостоянной основе, не покидая той профессиональной позиции (например, в бизнесе или в социальной сфере), которую занимали на момент избрания в легислатуру.

В-третьих, особенности источников рекрутирования и карьеры региональной политической элиты могут быть связаны с уровнем ее сплоченности (интеграции). Вообще гомогенность (однородность) социально-профессионального профиля парламентариев может служить важной предпосылкой элитной сплоченности, облегчать внутриэлитный компромисс, способствовать развитию корпоративного духа [Kim, Patterson 1988: 380; Edinger 2010: 132]. Кроме того, значимым фактором и показателем интеграции различных функциональных сегментов элиты служат динамические переплетения между ними, создаваемые карьерными переходами персон из одних властных групп в другие. В этом смысле, например, приток в региональные легислатуры выходцев из административных структур или экономической элиты региона может способствовать межфракционной элитной интеграции, формированию единой, хотя и дифференцированной в институциональном и функциональном отношениях властной элиты региона.

Наконец, в-четвертых, характер бассейна рекрутирования политической элиты, включая региональных депутатов, может влиять на ее легитимность. Как писал Р. Патнэм, политическая легитимность частично основывается на представлении о равенстве возможностей, и, как полагают многие практические политики, социологически непредставительная элита может подрывать легитимность правления ([Putnam 1976: 44]; см. также: [Matthews 1984: 556]). В связи с этим вопрос о том, в какой степени социально-профессиональный состав легислатур соответствует социально-структурным характеристикам населения соответствующих регионов, имеет существенное значение.

\section{ОПИСАНИЕ ВЫБОРКИ И БАЗЫ ДАННЫХ}

Исследование основано на анализе биографий российской региональной политической элиты с использованием структурно-биографического метода, в рамках которого структура региональных элитных 
групп изучается в связи с биографией персон, входящих в эти группы [Быстрова и др. 2008: 158]. Стратегия исследования предполагает первоначальный сбор информации о происхождении, карьерах, деловых связях, собственности элитных персон. Далее из общего массива данных выделяется информация, имеющая значение для поставленных в исследовании задач. Эти данные помещаются в структурированные биографические анкеты, после чего осуществляется кодирование данных в значения переменных и ввод в матрицу данных на базе статистического пакета SPSS.

База данных сформирована по законодательным органам власти десяти субъектов федерации: Москвы, Санкт-Петербурга, Ленинградской, Калининградской, Костромской, Ростовской и Новосибирской областей, Ставропольского и Хабаровского края, а также Республики Дагестан. Выбор этих регионов обусловлен несколькими факторами, влияющими на формирование структур не только политической, но и административной и экономической элиты региона. Во-первых, среди рассматриваемых нами случаев представлены различные формы административно-территориального деления: два региона - города федерального значения, четыре региона демонстрируют областной тип территориального деления и еще два - краевой, один из выбранных регионов является национальной республикой. При этом одна из областей, Ленинградская, по ряду показателей образует макрорегион вместе с Санкт-Петербургом: будучи промышленным, экономическим и образовательным центром для всей области, город является также «поставщиком» политической элиты в областное Законодательное собрание.

Во-вторых, в исследовании представлены различные типы региональных экономик. В ряде регионов значимыми отраслями являются транспортная инфраструктура и торговля (Ленинградская и Калининградская области). В других преобладает сельское хозяйство (Ставропольский край, Костромская область), лесозаготовительная (Хабаровский край) и добывающая промышленность (Ростовская область, Республика Дагестан). Ряд регионов - крупные промышленные и научные центры (Москва, Санкт-Петербург, Новосибирская область). Экономические факторы рассматривались нами как значимые в отношении карьерных траекторий элиты, совмещения позиций в политике и бизнесе и горизонтальной мобильности представителей элиты.

B-третьих, значимым фактором является профессиональная структура региональных парламентов и правовой статус депутатов в ней. 
В выборке представлены как полностью профессиональные органы власти (ЗАКС Санкт-Петербурга), так и те, в которых парламентарии, работающие на постоянной основе, составляют половину или четверть от всех членов депутатского корпуса. Представленные в выборке органы власти также разнятся по численности депутатов. Общая численность региональных депутатов в выборке - 536 позиций. Кроме того, были собраны данные о представителях федеральной политической элиты данных регионов: депутатах Государственной Думы РФ и членах Совета Федерации. Общее количество наблюдений в базе - 660 случаев (табл. 1).

Таблиияа 1

Федеральная и региональная элита по регионам

\begin{tabular}{|c|c|c|c|}
\hline \multirow{2}{*}{ Регион } & \multicolumn{2}{|c|}{ Уровень элиты } & $\begin{array}{c}\text { Всего } \\
\text { погиону }\end{array}$ \\
\cline { 2 - 3 } & федеральная & региональная & \\
\hline Санкт-Петербург & 15 & 50 & 65 \\
\hline Ленинградская обл. & 9 & 51 & 60 \\
\hline Ростовская обл. & 15 & 61 & 76 \\
\hline Калининградская обл. & 10 & 41 & 51 \\
\hline Костромская обл. & 3 & 38 & 41 \\
\hline Хабаровский край & 7 & 40 & 47 \\
\hline Москва & 28 & 45 & 73 \\
\hline Новосибирская обл. & 10 & 76 & 86 \\
\hline Ставропольский край & 10 & 50 & 60 \\
\hline Республика Дагестан & 11 & 90 & 101 \\
\hline Всего & 118 & 542 & 660 \\
\hline
\end{tabular}

Сбор биографической информации осуществлялся из открытых источников, таких как официальные веб-страницы региональных законодательных органов, федеральные и региональные онлайн-справочники («Замполит», «Виперсон.ру», «Руспех», «Российская энциклопедия кандидатов», «ЛФ-Выборы»'1), интервью и новостные публикации в СМИ.

${ }^{1}$ Viperson [http://viperson.ru/], главный ресурс политинформации «Замполит» [http://zampolit.com], Российская энциклопедия кандидатов [https:// candidates.golosinfo.org/], Руспех.py [https://ruspekh.ru/people], информационносправочная система «ЛФ-Выборы» [https://www.leftfront.org/elections/]. Дата обращения ко всем ресурсам: 17.12.2019. 
Значимым источником информации в ряде случаев стали публичные страницы парламентариев в социальных сетях. Как показывает анализ О.В. Крыштановской, использование социальных сетей становится распространенной практикой среди представителей по крайней мере федеральной политической элиты: доля представленности депутатов Государственной Думы в соцсетях составляет 81 \%, сенаторов - 37 \% [Крыштановская 2019: 7]. Данные об участии в бизнесе, а также декларации о доходах и собственности были собраны из разделов «Сведения о доходах» федеральных и региональных законодательных органов, а также из онлайн-баз данных деклараций и юридических лиц, таких как «Rusprofile» и «Декларатор» ${ }^{1}$.

\section{КАРЬЕРЫ}

Исследование карьер политиков разного уровня проводятся во многих странах уже довольно продолжительное время. Сложилось несколько исследовательских подходов, которые можно представить как два кластера. В центре одного - политические акторы, в центре другого социальный контекст. Поскольку карьеры, их типичные траектории не только описывают судьбы индивидов, принадлежащих к различным социальным группам, но и являются вектором действия различных факторов (с одной стороны, личных качеств индивида, с другой стороны, социальный контекст, определяющий структуру возможностей для индивида и ресурсы для реализации этих возможностей), такое рассмотрение подходов вполне правомерно. Это позволяет объединить достижения авторов, работающих в различных научных дисциплинах, и анализировать карьеры, в нашем случае политические, в различных аспектах.

Призывы к междисциплинарности, как и интенции каким-то образом интегрировать теоретические подходы к исследованию карьер, звучат давно. Предпринимались практические попытки. Например, объединить психологические установки индивидов и социальный контекст в рамках теории амбиций [Schlesinger 1966; Black 1972; Nicholls 1991; Herrick, Moore 1993; Hall, van Houweling 1995; Lawless 2012; Öhberg

${ }^{1}$ Онлайн-база деклараций «Декларатор» [https://declarator.org], онлайнбаза юридических лиц [https://www.rusprofile.ru/]. Дата обращения ко всем ресурсам: 17.12.2019. 
2017]. М. Верчези описывает оба кластера, сделав при этом в форме двух таблиц свод независимых переменных, основных аргументов, используемых методов и ограничений (недостатков) каждого из них [Vercesi 2018]. Главное состоит в его попытке найти комплексный подход, ведь эти точки зрения не являются взаимоисключающими, скорее они дополняют друг друга. Соображения автора в этом направлении представляются вполне адекватными задачам исследования политических карьер. В частности, он предлагает избегать любого детерминизма, поскольку структурные факторы оставляют достаточно большое пространство для выбора индивидом своих карьерных решений, а вариативность выбора карьеры существует в рамках одного и того же социального контекста. Структурные возможности макроуровня, включая страновые факторы и типы режимов ${ }^{1}$, определяют рамки, в которых политики ищут посты (должности, позиции) и принимают карьерные решения. Организации и институты (мезоуровень) влияют на индивидуальные стратегии, т.е. выступают посредниками между макро- и микроуровнями. Диапазон выбора ограничен контекстом, его заданность может воспроизводиться, однако резкие изменения могут переменить ситуацию и привести к межэлитной циркуляции.

То есть комплексный подход должен учитывать глубокие социальные изменения, не только как результат, но и как процесс. Эта точка зрения встречается довольно часто и у отечественных исследователей, если и не всегда сформулированная прямо, то как часть методологии, описывающая политические карьеры и изменения каналов и бассейнов рекрутирования в качестве механизма элитной трансформации, которая является частью более широкого процесса трансформации общества и государства [Гаман-Голутвина 2006; Крыштановская 2004; Куколев 1997].

Из существующего множества типологий, созданных под различные задачи, исходя из нужд исследователей, работающих в различных дисциплинах, нами выбрана наиболее адекватная нашим целям классификация карьер как профессиональных и социальных, т.е. по критерию приверженности индивидов в карьере определенным видам деятельности.

Профессиональный тип карьер - это, как правило, последовательное прохождение ступеней карьерной лестницы в рамках преимущественно одного вида деятельности.

${ }^{1}$ Демократические лидеры отличаются от лидеров автократических режимов, существуют также значительные различия между автократиями [Baturo 2016]. 
Социальный тип - когда в процессе последовательного восхождения по карьерной лестнице происходит неоднократная смена видов деятельности. Иногда такой тип карьеры называют еще структурным.

В исследованиях трансформации российских элит встречаем немало метафорически обозначенных типов карьер, «типичных представителей»: «прагматик-индустриалист», «прагматик-постиндустриалист», «прагматик-традиционалист», «партийно-комсомольский карьерист», «этатистдержавник», «популист-политик» и «новый делец-политик» [Буренкова 1995]; «служаки-спринтеры», «служаки-стайеры», «выскочки-директора», «выскочки-ученые», «выскочки-предприниматели» и «выскочки-разночинцы» [Понеделков 1995]; «прагматик», «хозяйственник», «директор», «партийный функционер», «администратор», «преподаватель», «прораб», «комсомолец» [Слепцов, Куколев, Рыскова 1997]; бизнесмен, промышленник, чиновник, силовик, публичная персона, бывший партиец, профессионал, общественный деятель [Селезнев и др. 2010].

В этих метафорах зафиксированы основные черты типов карьер и бассейны рекрутирования.

К началу 1980-х годов (период застоя) преобладающий тип карьеры - профессиональный. Период рубежа 1980-1990-х годов, даже немного ранее, и до середины 1990-х - сдвиг в сторону социального типа [Куколев 1997].

Наши исследования региональных элит начиная с 1998 г. показали, что преобладающий тип карьер в бизнес-элите - профессиональный. В среде административно-политической элиты большее значение имели социальные карьеры (2000-е годы). Дальнейшие исследования показали возрастание в элите доли лиц, имеющих профессиональную карьеру по показателям предшествующей, предпредшествующей работы, с учетом последней предэлитной должности. Из элиты постепенно почти исчезли бывшие политические активисты, представители низкостатусных групп.

О влиянии региональных законодательных норм на уровень профессионализации депутатов уже говорилось ранее в связи с имеющимися ограничениями числа членов законодательных собраний, которые могут работать на профессиональной основе. Параллельные позиции депутатов, работающих на непрофессиональной основе, представлены в основном различными должностями в коммерческих компаниях. Нередки позиции руководителей медицинских и образовательных учреждений. 
Анализ в разрезе принадлежности к политическим поколениям подтверждает предположение о влиянии различного рода турбулентностей в обществе на характер карьеры. Причем в двух направлениях - как период первичной и профессиональной социализации и как период делания карьеры. Так, карьеры представителей регионального высшего чиновничества поколения застоя выглядят более профессиональными, чем карьеры лиц, относящихся к поколениям перестройки и кризиса. Последние имеют в траекториях своих карьер больше зигзагов, связанных с переменой сфер деятельности. Связь типа карьеры с принадлежностью к определенному поколению была зафиксирована как для региональных чиновников, так и для региональных политиков. По некоторым показателям характер связи сходен у обеих групп, по другим - отличен [Быстрова 2017].

Исследование региональных депутатов 2019 г. выявило, что 63 \% политиков вступили в нынешнюю должность в среднем возрасте. Только 18 \% вступили в нынешнюю должность, будучи молодыми - в возрасте от 22 до 40 лет, 19 \% в пенсионном возрасте (табл. 2).

Таблица 2

Возраст избрания в депутаты, $\mathrm{N}=660$

\begin{tabular}{|c|c|c|c|}
\hline \multirow{2}{*}{ Регион } & \multicolumn{3}{|c|}{ вступление в должность/поколения, \% } \\
\cline { 2 - 4 } & $\begin{array}{c}\text { Молодые } \\
(\mathbf{2 2 - 4 0} \text { лет) }\end{array}$ & $\begin{array}{c}\text { Средний } \\
\text { возраст } \\
(\mathbf{4 1 - 6 0} \text { лет) }\end{array}$ & $\begin{array}{c}\text { Пенсионеры } \\
\text { (старше 60 лет) }\end{array}$ \\
\hline Санкт-Петербург & 21 & 54 & 25 \\
\hline Ленинградская обл. & 17 & 65 & 18 \\
\hline Ростовская обл. & 20 & 64 & 16 \\
\hline Калининградская обл. & 17 & 67 & 7 \\
\hline Костромская обл. & 25 & 68 & 19 \\
\hline Хабаровский край & 15 & 66 & 27 \\
\hline Москва & 11 & 62 & 19 \\
\hline Новосибирская обл. & 15 & 62 & 17 \\
\hline Ставропольский край & 17 & 64 & 19 \\
\hline Республика Дагестан & 20 & 63 & 63 \\
\hline Итого & 18 & & 23 \\
\hline
\end{tabular}

Два года и менее занимают свои нынешние должности 11 \% политиков. Подавляющее большинство остаются на нынешних позициях от трех до пяти лет (88 \%). Более пяти лет - доли процента. Если учесть 
тех, кто занимает нынешнюю позицию не более двух лет, то получим удивительную величину показателя: 99 \% региональных политиков рассматриваемых десяти регионов занимают свои должности менее пяти лет. При этом 61 \% региональных политиков - «новички» в политической элите. Это их первая элитная должность в биографии. Для $21 \%$ региональных политиков нынешняя элитная должность - вторая в карьере, еще для 10 \% - третья. И всего для 8 \% политиков - четвертая и более элитная позиция (табл. 3).

Таблиияа 3

Номер элитной должности в биографии депутатов, N=594

\begin{tabular}{|c|c|c|c|c|}
\hline \multirow[b]{2}{*}{ Регион } & \multicolumn{4}{|c|}{$\begin{array}{c}\text { Номер } \\
\text { элитной должности в биографии (какая по счету), \% }\end{array}$} \\
\hline & $\begin{array}{c}\text { первая } \\
\text { (элитная } \\
\text { должность - } \\
\text { «новичок» } \\
\text { в элите) }\end{array}$ & $\begin{array}{c}\text { вторая } \\
\text { элитная } \\
\text { должность }\end{array}$ & $\begin{array}{c}\text { третья } \\
\text { элитная } \\
\text { должность }\end{array}$ & $\begin{array}{c}\text { четвертая } \\
\text { и далее } \\
\text { элитная } \\
\text { должность }\end{array}$ \\
\hline Санкт-Петербург & 72 & 14 & 2 & 12 \\
\hline Ленинградская обл. & 67 & 18 & 10 & 5 \\
\hline Ростовская обл. & 57 & 18 & 13 & 12 \\
\hline $\begin{array}{l}\text { Калининградская } \\
\text { обл. }\end{array}$ & 45 & 23 & 16 & 16 \\
\hline Костромская обл. & 61 & 22 & 12 & 5 \\
\hline Хабаровский край & 66 & 21 & 4 & 9 \\
\hline Москва & 72 & 16 & 5 & 7 \\
\hline $\begin{array}{l}\text { Новосибирская } \\
\text { обл. }\end{array}$ & 64 & 26 & 7 & 3 \\
\hline $\begin{array}{l}\text { Ставропольский } \\
\text { край }\end{array}$ & 55 & 24 & 8 & 13 \\
\hline $\begin{array}{l}\text { Республика } \\
\text { Дагестан }\end{array}$ & 41 & 27 & 32 & 0 \\
\hline Итого & 61 & 20 & 10 & 8 \\
\hline
\end{tabular}

В то же время более половины заняли нынешнюю элитную позицию впервые, 22 \% на данной должности во второй раз, $12 \%-$ в третий и $13 \%$ - в четвертый и более раз. То есть почти половина политиков свой политический пост занимает не первый раз в карьере.

Чем же занимались наши политики до занятия первой элитной позиции, из какой сферы они рекрутировались? 
Анализ сферы предэлитной активности (т.е. предшествующей вступлению в первую элитную должность) показывает, что более половины (52 \%) политиков были заняты хозяйственно-экономической деятельностью, еще 29 \% - политико-административной. Только у 4 \% работа была связана с силовыми структурами. Прочие виды деятельности дают почти 15 \%. Работа в коммерческих структурах в основном представлена высшими позициями в менеджменте компаний и в небольшом количестве должностями, относящимися к среднему уровню управления. Политико-административная деятельность в предэлитный период протекала в аппаратах представительных органов власти федерального и регионального уровней (должности руководителя аппарата, помощника депутата), нередко в областной и районной администрации (должности среднего и нижнего уровня), а также в представительных органах муниципального и районного уровня (муниципальный депутат, сотрудник представительного органа муниципального или районного уровня). На весь массив всего два бывших члена избиркома федерального и регионального уровня.

Показатель возраста вступления в предэлитную должность (табл. 4) демонстрирует, что почти 60 \% политиков, в биографиях которых есть соответствующие сведения, вступили в предэлитную должность в молодом возрасте (до 40 лет), 38 \% - в среднем возрасте (от 41 до 60 лет) и около $2 \%$ - после 60 лет. По данному показателю региональные различия довольно велики. В молодом возрасте заняли предэлитную должность значительное большинство (68 \%) политиков Костромской области и Республики Дагестан. В Калининградской, Ростовской и Новосибирской областях и Ставропольском крае показатель также выше, чем в целом по массиву. В остальных регионах величина доли тех, кто занял предэлитную должность в молодом возрасте, ниже, чем по массиву в целом. Это Хабаровский край (44 \%), Ленинградская область (50 \%), Санкт-Петербург (55 \%) и Москва (58 \%). Более раннее вступление в предэлитную должность отразилось на показателе возраста вступления в нынешнюю должность, по этому показателю лидируют Костромская область и Республика Дагестан. Можно предположить, что объяснение этому феномену лежит также в более коротких сроках пребывания на предэлитной позиции.

Возраст вступления в нынешнюю должность. В молодом возрасте (до 40 лет) вступили в нынешнюю должность политики Костромской области, Санкт-Петербурга и Республики Дагестан $(24,21$ и 20 \% соот- 
ветственно). По данному показателю эти три субъекта РФ являются лидерами. В Костромской области меньше всего доля тех, кто занял нынешнюю должность в возрасте старше 60 лет (7 \%). Больше всего доля таких политиков в Москве (27 \%), Санкт-Петербурге (25 \%) и Новосибирской области (23\%).

Таблииза 4

Возраст вступления в предэлитную должность, $\mathrm{N}=521$

\begin{tabular}{|c|c|c|c|}
\hline \multirow{2}{*}{ Регион } & \multicolumn{3}{|c|}{$\begin{array}{c}\text { Возраст вступления в предэлитную } \\
\text { должность / поколения, \% }\end{array}$} \\
\cline { 2 - 4 } & $\begin{array}{c}\text { Молодые } \\
(\mathbf{2 2 - 4 0} \text { лет) }\end{array}$ & $\begin{array}{c}\text { Средний возраст } \\
\mathbf{( 4 1 - 6 0 ~ л е т ) ~}\end{array}$ & $\begin{array}{c}\text { Пенсионеры } \\
\text { (старше } \\
\mathbf{6 0} \text { лет) }\end{array}$ \\
\hline Санкт-Петербург & 55 & 44 & 1 \\
\hline Ленинградская обл. & 50 & 50 & 0 \\
\hline Ростовская обл. & 65 & 32 & 3 \\
\hline Калининградская обл. & 65 & 35 & 0 \\
\hline Костромская обл. & 68 & 32 & 4 \\
\hline Хабаровский край & 45 & 51 & 4 \\
\hline Москва & 58 & 38 & 0 \\
\hline Новосибирская обл. & 61 & 35 & 2 \\
\hline Ставропольский край & 63 & 37 & 4 \\
\hline Республика Дагестан & 68 & 32 & 0 \\
\hline Итого & 60 & 38 & \\
\hline
\end{tabular}

Продолжительность времени занятия нынешней политической позииии. Подавляющая часть политиков занимают свою нынешнюю должность от трех до пяти лет во всех регионах, кроме Ростовской области. Здесь таких политиков очень немного - всего 17 \%. В этом же субъекте РФ велика доля тех, кто пребывает в должности два года и менее (82 \%).

«Новички» в политике, т.е. те, у кого занимаемая элитная должность первая в карьере, преобладают в восьми регионах из рассматриваемых десяти. Причем если в целом по массиву таких 61 \%, то в некоторых субъектах РФ существенно выше, достигая максимума в СанктПетербурге и Москве (72 \%) и колеблясь в диапазоне от уже упомянутых 72 \% в Санкт-Петербурге и Москве до 55 \% в Ставропольском крае. Наименьшая доля «новичков» зафиксирована среди политиков Республики Дагестан (42 \%). Следом идет Калининградская область (45 \%) (см. табл. 3). 
Более половины политиков по массиву в целом не просто «новички» в элите, они еще и в первый раз заняли нынешнюю должность. Меньше всего впервые оказавшихся на своей должности в Новосибирской области (42\%). Лидерами по числу двойных «новичков» (доли тех, кто впервые попал в элиту и первый раз на данной должности) являются Хабаровский край, Калининградская область: 66 и 63 \% соответственно (табл. 5).

Таблица 5

Номер данной элитной позиции в биографии (в который раз субъект получает эту должность), $\mathrm{N}=589$

\begin{tabular}{|c|c|c|c|c|}
\hline \multirow[b]{2}{*}{ Регион } & \multicolumn{4}{|c|}{$\begin{array}{c}\text { Номер данной элитной позиции в биографии } \\
\text { (в который раз субъект получает эту } \\
\text { должность), \% }\end{array}$} \\
\hline & $\begin{array}{c}\text { первый раз } \\
\text { занимает } \\
\text { данную } \\
\text { позицию - } \\
\text { «новичок» } \\
\text { в этой } \\
\text { должности }\end{array}$ & $\begin{array}{c}\text { второй } \\
\text { раз }\end{array}$ & $\begin{array}{c}\text { третий } \\
\text { раз }\end{array}$ & $\begin{array}{c}\text { четвертый } \\
\text { раз } \\
\text { и далее }\end{array}$ \\
\hline Санкт-Петербург & 61 & 25 & 3 & 11 \\
\hline Ленинградская обл. & 52 & 18 & 18 & 12 \\
\hline Ростовская обл. & 60 & 24 & 9 & 7 \\
\hline Калининградская обл. & 63 & 16 & 13 & 8 \\
\hline Костромская обл. & 59 & 19 & 10 & 12 \\
\hline Хабаровский край & 66 & 23 & 7 & 4 \\
\hline Москва & 44 & 15 & 13 & 28 \\
\hline Новосибирская обл. & 42 & 20 & 17 & 21 \\
\hline Ставропольский край & 48 & 35 & 15 & 2 \\
\hline Республика Дагестан & 44 & 14 & 17 & 25 \\
\hline Итого & 53 & 21 & 13 & 13 \\
\hline
\end{tabular}

Показатель предэлитной активности политиков в политико-административной сфере самый высокий в Санкт-Петербурге (53 \%). Одновременно здесь самый низкий показатель предэлитной активности политиков в хозяйственно-экономической сфере - 27 \%. Больше всего хозяйственно-экономическая сфера как предэлитная деятельность значима для Костромской и Новосибирской областей (73 и 69 \% соответственно). Республика Дагестан отличается самым высоким значением 
силовых структур в качестве сферы предэлитной деятельности (10 против 4 \% в целом по массиву). Несколько больше, чем в целом по массиву, доля политиков с силовым прошлым (предэлитная деятельность в силовых структурах) в Ленинградской (7 \%) и Калининградской (8 \%) областях (табл. 6).

Таблица 6

Предэлитная активность (сфера деятельности, непосредственно предшествующая первой в биографии элитной должности), $\mathrm{N}=612$

\begin{tabular}{|c|c|c|c|c|}
\hline \multirow[b]{2}{*}{ Регион } & \multicolumn{4}{|c|}{$\begin{array}{c}\text { Предэлитная активность (сфера деятельности, } \\
\text { непосредственно предшествующая первой } \\
\text { в биографии элитной должности), \% }\end{array}$} \\
\hline & $\begin{array}{c}\text { политико- } \\
\text { администра- } \\
\text { тивная } \\
\text { активность } \\
\end{array}$ & \begin{tabular}{|c|} 
хозяйственно- \\
экономи- \\
ческая \\
активность
\end{tabular} & силовик & $\begin{array}{c}\text { прочая } \\
\text { активность }\end{array}$ \\
\hline Санкт-Петербург & 53 & 27 & 5 & 15 \\
\hline Ленинградская обл. & 36 & 37 & 7 & 20 \\
\hline Ростовская обл. & 25 & 57 & 1 & 17 \\
\hline $\begin{array}{c}\text { Калининградская } \\
\text { обл. }\end{array}$ & 23 & 53 & 8 & 16 \\
\hline Костромская обл. & 10 & 73 & 0 & 17 \\
\hline Хабаровский край & 25 & 60 & 2 & 13 \\
\hline Москва & 41 & 37 & 3 & 19 \\
\hline $\begin{array}{c}\text { Новосибирская } \\
\text { обл. }\end{array}$ & 19 & 69 & 4 & 8 \\
\hline $\begin{array}{c}\text { Ставропольский } \\
\text { край }\end{array}$ & 26 & 59 & 5 & 10 \\
\hline $\begin{array}{c}\text { Республика } \\
\text { Дагестан }\end{array}$ & 27 & 52 & 10 & 11 \\
\hline Итого & 29 & 52 & 4 & 15 \\
\hline
\end{tabular}

Номенклатурный опыт в карьере обнаруживается у 12 \% политиков рассматриваемых регионов. При этом в группе в 118 политиков федерального уровня (депутаты ГД и СФ ФС РФ) их 20 человек (17\%), из 542 региональных депутатов - 57 человек (10 \%). По сравнению с нашими исследованиями региональных элит более ранних периодов (по восьми регионам - без Ставропольского края и Республики Дагестан) доля бывших номенклатурных работников среди политиков уменьшилась [Быстрова 2017]. 
В более ранние годы формирования региональной политической элиты в ее составе было немало лиц, имевших номенклатурный опыт разного уровня в советское время. Довольно большое число лиц, имеющих номенклатурный опыт, в составе региональной элиты связано с тем, как проходило формирование элитного корпуса в постсоветский период. В частности, исследователи отмечали, что первый постсоветский период характеризовался острейшей конкуренцией фракций номенклатуры, образовавшихся в результате ее раскола и принявших вид многопартийности [Гудков 2011]. Продолжалась масштабная приватизация государственной собственности партийно-советской номенклатурой, начавшаяся еще в последние годы существования СССР. «Аппарат торопился приобщиться к собственности», а «уход из номенклатуры перестал быть трагедией, как было раньше» [Пихоя 2011]. Исследование трансформации элитных структур регионов показывало, что «черты видового сходства» определяются «генетической общностью их происхождения как продукта советской номенклатурной системы» [Латыпов 2009] ${ }^{1}$. Исследования, проводившиеся в Институте социологии РАН в 1989-1994 гг., показали, что в постперестроечный период треть депутатов уже не имела номенклатурного прошлого. Однако 82 \% представителей региональной элиты - бывшие «номенклатурщики» [Крыштановская 1995].

В нашем исследовании доля тех, кто имеет в карьере номенклатурный опыт, наиболее значимой оказывается работа в партийных органах времен СССР. Большая доля номенклатурной деятельности осуществлялась в райкомах партии или партийных органах более высокого уровня. Много меньшее значение имела низовая партийная работа в парткомах на предприятиях. Комсомол с точки зрения «делания» карьеры также имел значение, меньшее, чем партийная деятельность, но существенно большее, чем работа в советских органах власти или в профсоюзе. Картина по регионам довольно разнообразная. Удельный вес политиков, имеющих номенклатурный опыт, колеблется в диапазоне от 20 \% в Костромской области до 6 \% в Республике Дагестан при средней доле по выборке 12 \% (77 человек). При этом в некоторых субъектах РФ (Санкт-Петербург и Костромская область) в составе региональной политической элиты практически нет персон, имеющих

${ }^{1}$ Исследование элит трех субъектов РФ: Татарстана, Башкортостана и Белгородской области. 
в своей карьере опыт работы в партийных органах уровня райкома и выше. В других (Ставропольский и Хабаровский край, Ростовская область) доля таких лиц весьма велика. По поводу уровня номенклатурного опыта можно сказать, что деятельность в рамках предприятия имеет небольшое значение, за исключением Костромской и Ленинградской областей. В трех субъектах РФ (Санкт-Петербург, Калининградская область и Республика Дагестан) персон с низовым номенклатурным опытом нет вовсе. В остальных пяти субъектах (Ростовская и Новосибирская области, Хабаровский и Ставропольский края, Москва) доля невелика. Следует иметь в виду, что в абсолютных значениях это очень небольшие величины.

Служба в силовых ведомствах. Роль службы в силовых ведомствах в делании карьеры российских политиков и чиновников неоднократно становилась предметом обсуждения [Дука 2012]. Исследовалось военное образование и то, какие личностные качества оно формирует. Каким образом и почему попадают бывшие военные в сферу государственного управления и органы представительной власти. Оценивалось возможное влияние бывших силовиков на качество формирующейся элиты. На данный момент можно резюмировать результаты следующим образом. Военное образование, конечно, формирует особенные качества личности, среди которых умение вписаться в военную иерархию, дисциплинированность, исполнительность, ответственность и другие того же ряда. Силовые структуры, в частности армия, до сих пор во многом формирующаяся принудительно, страдают от бед закрытых сообществ. Фактически неограниченная власть над нижестоящими, подчиненными, с одной стороны, и привычка бездумного подчинения - с другой. Люди, прошедшие этот институт как инициацию во взрослую жизнь («срочники») или отдавшие службе значительное количество лет своей сознательной жизни, получают вполне определенный жизненный опыт и являются носителями известных качеств, умений и навыков, не всегда адекватных гражданской жизни. Данные, которые публиковались даже известными исследователями, оказывались неточными. Они преувеличивали удельный вес силовиков. В то же время верно угадывали силу их влияния.

Во времена СССР карьера партийного или советского работника предполагала как почти обязательную ступень (для мужчин) срочную службу. Кроме того, она давала льготы при получении высшего образования. Теперь же в нашем массиве политиков десяти регионов 
из 660 персон имеют силовой опыт 127 человек (19\%). При этом среди депутатов ГД и членов СФ от регионов их $21 \%$, доля имеющих в биографиях службу в силовых структурах среди депутатов региональных законодательных органов чуть превышает 19 \%. Те, кто отдали службе не более трех лет, составляют небольшую долю: 4 \% среди региональных депутатов и 8 \% среди ГД и членов СФ. Это как раз те, кто, скорее всего, прошел срочную службу в армии. Остальные являлись кадровыми офицерами различных силовых структур. Довольно много среди политиков тех, кто прослужил десять лет и более. Они составляют немного меньше половины всех имеющих силовой опыт среди депутатов ГД и членов СФ от рассматриваемых регионов и больше трети региональных депутатов.

Таблица 7

Служба в силовых ведомствах, $\mathrm{N}=127$

\begin{tabular}{|c|c|c|c|c|}
\hline \multirow[t]{2}{*}{ Регион } & \multicolumn{3}{|c|}{$\begin{array}{c}\text { Силовой опыт по категориям } \\
\text { (человек / \%) }\end{array}$} & \multirow[t]{2}{*}{ Итого } \\
\hline & $\begin{array}{c}5 \text { лет } \\
\text { и меньше }\end{array}$ & 6-9 лет & $\begin{array}{c}10 \text { лет } \\
\text { и больше }\end{array}$ & \\
\hline \multirow{2}{*}{ Санкт-Петербург } & 4 & 5 & 15 & 24 \\
\hline & 16,7 & 20,8 & 62,5 & 100,0 \\
\hline \multirow{2}{*}{ Ленинградская обл. } & 5 & 3 & 6 & 14 \\
\hline & 35,7 & 21,4 & 42,9 & 100,0 \\
\hline \multirow{2}{*}{ Ростовская обл. } & 14 & 0 & 1 & 15 \\
\hline & 93,3 & 0,0 & 6,7 & 100,0 \\
\hline \multirow{2}{*}{$\begin{array}{c}\text { Калининградская } \\
\text { обл. }\end{array}$} & 13 & 3 & 10 & 26 \\
\hline & 50,0 & 11,5 & 38,5 & 100,0 \\
\hline \multirow{2}{*}{ Костромская обл. } & 13 & 2 & 2 & 17 \\
\hline & 76,5 & 11,8 & 11,8 & 100,0 \\
\hline \multirow{2}{*}{ Хабаровский край } & 8 & 2 & 4 & 14 \\
\hline & 57,1 & 14,3 & 28,6 & 100,0 \\
\hline \multirow{2}{*}{ Москва } & 1 & 3 & 3 & 7 \\
\hline & 14,3 & 42,9 & 42,9 & 100,0 \\
\hline \multirow{2}{*}{ Новосибирская обл. } & 0 & 1 & 4 & 5 \\
\hline & 0,0 & 20,0 & 80,0 & 100,0 \\
\hline \multirow{2}{*}{ Ставропольский край } & 3 & 0 & 2 & 5 \\
\hline & 60,0 & 0,0 & 40,0 & 100,0 \\
\hline \multirow{2}{*}{ Итого } & 61 & 19 & 47 & 127 \\
\hline & 48,0 & 15,0 & 37,0 & 100,0 \\
\hline
\end{tabular}


Наиболее распространенный срок службы среди категории прослуживших десять и более лет - от 10 до 19 лет, т.е. это люди, скорее всего, прослужившие практически все время, необходимое для получения пенсии в силовых структурах. Тех, кто прослужил 20 лет и более, 18 человек, т.е. 14 \% от общего числа имеющих силовой опыт (3\% от всего массива политиков десяти регионов). Лидерами по доле заслуженных силовиков являются политики Новосибирской области и СанктПетербурга: 80 и 62 \% от числа тех, кто имеет силовой опыт. Меньше всего эта доля в Ростовской области - 7 \% (1 человек) (табл. 7).

Большая часть политиков, в чьих биографиях есть силовой опыт, имеют звания старших офицеров (майор, подполковник, полковник): $57 \%$ в федеральной и $75 \%$ в региональной элите. Персон, имеющих высшие офицерские звания (генерал-майор и выше), очень немного: два человека в федеральной и пять человек в региональной элите ${ }^{1}$.

\section{ХАРАКТЕРИСТИКИ БАССЕЙНА РЕКРУТИРОВАНИЯ}

Анализ бассейна рекрутирования региональной политической элиты позволяет с другой стороны посмотреть на профессиональную карьеру депутатов. Приведенные ниже таблицы 8-10 фиксируют работу и сферу активности членов региональной политической элиты до вхождения в нынешнюю должность и в различные годы постсоветского периода, позволяя выявить основные как непосредственные, так и косвенные социально-профессиональные источники их рекрутирования.

Из приведенных ниже таблиц можно сделать вывод о том, что важными тенденциями рекрутирования и карьеры региональной политической элиты являются профессионализация, бюрократизация, плутократизация и социальная закрытость. Далее они будут рассмотрены подробнее.

${ }^{1}$ Сведения о воинских/военизированных званиях имеются только по 50 персонам, что в 2,5 раза меньше общего числа политиков, в биографиях которых есть силовой опыт. 
Таблица 8

Работа членов политической элиты, предшествующая нынешней должности, $\mathrm{N}=603$

\begin{tabular}{|c|c|}
\hline Занятие & Предшествующая работа, \% \\
\hline Депутат & 49 \\
\hline Администратор & 11 \\
\hline Политический активист & 5 \\
\hline Хозяйственник, бизнесмен & 29 \\
\hline Специалист & 1 \\
\hline Наука, культура, образование & 3 \\
\hline Силовик & 1 \\
\hline Юрист & $\sim 0$ \\
\hline Медик & 1 \\
\hline Рабочий/колхозник & $\sim 0$ \\
\hline Учащийся & $\sim 0$ \\
\hline
\end{tabular}

Таблииа 9

Работа членов политической элиты, предпредшествующая нынешней должности, $\mathrm{N}=583$

\begin{tabular}{|c|c|}
\hline Занятие & Предпредшествующая работа, \% \\
\hline Политико-административная & 46 \\
\hline Хозяйственно-экономическая & 40 \\
\hline Силовик & 3 \\
\hline Другое & 11 \\
\hline
\end{tabular}

Таблиия 10

Занятие членов политической элиты в 1993, 1995, 2000, 2004, 2008, 2010 и 2014 гг. (в \%)

\begin{tabular}{|c|c|c|c|c|c|c|c|}
\hline Работа & $\begin{array}{c}\mathbf{1 9 9 3} \\
\mathbf{( N = 4 4 9 )}\end{array}$ & $\begin{array}{c}\mathbf{1 9 9 5} \\
\mathbf{( N = 4 8 6})\end{array}$ & $\begin{array}{c}\mathbf{2 0 0 0} \\
(\mathbf{N}=\mathbf{5 5 4})\end{array}$ & $\begin{array}{c}\mathbf{2 0 0 4} \\
\mathbf{( \mathbf { N } = 5 6 9 )}\end{array}$ & $\begin{array}{c}\mathbf{2 0 0 8} \\
(\mathbf{N}=\mathbf{5 7 8})\end{array}$ & $\begin{array}{c}\mathbf{2 0 1 0} \\
(\mathbf{N}=\mathbf{5 8 5})\end{array}$ & $\begin{array}{c}\mathbf{2 0 1 4} \\
(\mathbf{N}=\mathbf{5 9 4})\end{array}$ \\
\hline Депутат & 5 & 8 & 13 & 19 & 28 & 36 & 50 \\
\hline $\begin{array}{c}\text { Администра- } \\
\text { тор }\end{array}$ & 9 & 8 & 11 & 13 & 13 & 13 & 11 \\
\hline $\begin{array}{c}\text { Политический } \\
\text { активист }\end{array}$ & 3 & 2 & 3 & 5 & 4 & 4 & 5 \\
\hline $\begin{array}{c}\text { Хозяйствен- } \\
\text { ник, бизнесмен }\end{array}$ & 33 & 38 & 42 & 44 & 41 & 38 & 29 \\
\hline Специалист & 5 & 3 & 2 & 1 & 1 & 1 & 1 \\
\hline
\end{tabular}




\begin{tabular}{|c|c|c|c|c|c|c|c|}
\hline $\begin{array}{c}\text { Наука, } \\
\text { культура, } \\
\text { образование }\end{array}$ & 11 & 11 & 8 & 6 & 5 & 3 & 2 \\
\hline Силовик & 11 & 9 & 6 & 4 & 3 & 2 & 1 \\
\hline Охранник & $\sim 0$ & 1 & 1 & $\sim 0$ & $\sim 0$ & $\sim 0$ & 0 \\
\hline Юрист & 1 & 1 & 1 & 1 & 1 & 1 & $\sim 0$ \\
\hline Медик & 3 & 4 & 3 & 2 & 2 & 1 & 1 \\
\hline $\begin{array}{c}\text { Рабочий/ } \\
\text { колхозник }\end{array}$ & 1 & 1 & 1 & $\sim 0$ & 0 & 0 & $\sim 0$ \\
\hline Учащийся & 18 & 14 & 9 & 5 & 2 & 1 & 0 \\
\hline
\end{tabular}

Законодательный опыт и профессионализация. Как показывают наши предыдущие исследования, для региональной политической элиты в целом характерен существенный уровень профессионализации, хотя в этом отношении она заметно уступает административной элите [Быстрова и др. 2017]. Политическая профессионализация связана, хотя и не тождественна, с наличием законодательного опыта перед избранием в действующий созыв. Данные показывают, что в плане присутствия и длительности такого опыта депутатский корпус неоднороден. Так, 53 \% депутатов являются «новичками», т.е. ранее не избирались в данный представительный орган, тогда как примерно четверть избиралась в него не менее трех раз (учитывая действующий созыв), т.е. уже довольно длительное время заседает в легислатуре. Как бы то ни было, таблица 8 свидетельствует о том, что депутатский корпус разного уровня служит главным непосредственным источником рекрутирования действующих парламентариев: почти половина членов политической элиты на момент вступления в нынешнюю, депутатскую, должность были заняты законодательной работой. Кроме того, у 46 \% с политикоадминистративной, прежде всего депутатской, деятельностью, была связана предпредшествующая должность. О продолжительности законодательной работы региональных политиков свидетельствует и таблица 10. Как видим, в 1993 г. только каждый двадцатый нынешний депутат был законодателем. Однако в последующие годы эта доля неуклонно росла: в 2000 г. - уже примерно каждый восьмой, в 2004 г. - почти каждый пятый, в 2010 г. - более трети, а в 2014 г. половина членов региональной политической элиты занимали депутатскую позицию.

Впрочем, наблюдаются значительные различия между регионами. Наибольшая распространенность законодательного опыта непосредственно перед вхождением в нынешний созыв легислатуры характерна для де- 
путатского корпуса Москвы и Новосибирской области, 60 \% представителей которого на момент избрания уже занимали депутатскую позицию, тогда как в Дагестане этот показатель составлял всего 32 \%.

Говоря об исторической динамике, следует отметить, что сравнительный анализ данных за длительный период времени по четырем регионам (Санкт-Петербургу, Ленинградской, Ростовской и Калининградской областям) показал, что роль депутатского корпуса как непосредственного источника рекрутирования действующих парламентариев снизилась. Так, если в 2005-2007 гг. 59 \% членов политической элиты работали депутатами на момент вступления в должность, то в 2019 г. этот показатель составлял $46 \%$.

Отдельно нужно сказать о том, что распространенность законодательного опыта и связанная с ней профессионализация сильнее всего проявились среди высшей политической элиты (председатели законодательных собраний, их заместители, председатели комитетов): у 62,5 \% ее представителей (против 49 \% по всей совокупности) депутатской была предшествующая работа.

Вообще существенно выраженная (хотя и непреобладающая) тенденция воспроизводства депутатского корпуса от созыва к созыву неудивительна и отчасти объясняется политическими преимуществами инкумбентов, которые включают наличие навыков избирательной борьбы и парламентской деятельности; узнаваемость имени парламентариев, работа которых сравнительно широко освещается СМИ; штат помощников; возможность использования своей властной позиции и связанных с ней ресурсов для оказания услуг избирателям с целью обеспечения поддержки с их стороны, а также для налаживания связей в кругах элиты, благодаря чему приобретаются влиятельные союзники во время выборов [Erikson 1971: 395; Медведев 2010: 76-77; Григорьева 2012: 14-15]. В частности, то, что опыт законодательной работы позитивно связан с карьерными возможностями внутри легислатуры, с доступом к ее «командным высотам», подтверждается предыдущими исследованиями [Reuter, Turovsky 2014].

Однако тенденция к персональному воспроизводству, к преемственности «политического класса» может сдерживаться другими факторами. Во-первых, это сама процедура рекрутирования депутатов. В отличие от региональных чиновников, которые, кроме губернатора, назначаются на свои должности (хотя отчасти и с формального согласия легислатуры), депутаты избираются населением субъекта федерации. Меха- 
низм рекрутирования политической элиты является сравнительно более демократичным (даже в условиях в целом авторитарной системы), менее автономным и дает больший контроль над процессом ее формирования «внешним» по отношению к ней социально-профессиональным группам, выходцы (в том числе прямые) из которых прежде всего из бизнеса, довольно широко представлены в ее составе. Во-вторых, надо иметь в виду и то, что слабость легислатур (и региональных, и федеральной) как политических институтов, их подчиненность административным структурам и в связи с этим относительно ограниченные властные возможности, которые дает депутатский мандат, могут подрывать мотивацию к длительной законодательной карьере, стимулируя стремление парламентариев к переходу на более влиятельные позиции, например в органах исполнительной власти, и разрушая тем самым воспроизводство политической элиты.

Надо сказать, что воспроизводство депутатского корпуса, как и его обновление, имеет противоречивые последствия [Putnam 1976: 66-67; Best et al. 2001: 80; Shabad, Slomczynski 2002: 333; Matland, Studlar 2004: 88-89; Ilonszki, Edinger 2007: 157]. С одной стороны, преемственность персонального состава представительных органов может негативно влиять на инновационность и гибкость политической системы, а также восприимчивость легислатур к меняющимся общественным интересам, способствовать изоляции законодателей от народа. С другой стороны, высокий уровень сменяемости законодательной элиты может подрывать развитие ее компетентности, усвоение ролей, препятствовать формированию корпоративного духа и тем самым снижать эффективность работы парламента, а также ослаблять его автономию по отношению к иным институтам (региональной администрации, бизнесу и пр.).

Как уже отмечалось, наличие предшествующего законодательного опыта не означает автоматически политическую профессионализацию, хотя и является ее необходимым условием. Здесь важно иметь в виду особенности правовых норм, регулирующих деятельность региональных депутатов. В отличие от чиновников всех уровней и депутатов Госдумы, которые обязаны работать на профессиональной основе и не вправе заниматься другой оплачиваемой деятельностью (кроме педагогической, научной, творческой), во многих регионах значительная часть депутатов вправе работать на непостоянной основе, совмещая свои полномочия с основной работой. Впрочем, в этом смысле ситуация сильно варьируется по исследуемым субъектам РФ. Так, Законодательное собрание 
Петербурга, по закону, работает полностью на профессиональной основе, то же самое можно было сказать и о Московской городской Думе пятого созыва, а вот в столичном парламенте шестого созыва положение изменилось, и только 18 из 45 депутатов вправе работать на освобожденной основе [Ульянова 2014]. В Новосибирской области на профессиональной основе могут работать не более 12 из 76 депутатов [Новосибирское заксобрание... 2018], в Калининградской областной думе - 22 из 40 [Романовский... 2018]; в Народном собрании Республики Дагестан - 32 из 90 народных избранников [Закон Республики Дагестан... 1995]. В Костромской областной Думе шестого созыва только 9 из 36 депутатов могут работать на постоянной основе [Закон Костромской области... 2009]. В Законодательной Думе Хабаровского края на постоянной основе могут работать не более половины депутатов [Только половина депутатов... 2014]. Таким образом, мы видим, что в силу особенностей институционального дизайна многих региональных парламентов и норм, регулирующих их функционирование, политическая элита, даже при ее существенном персональном воспроизводстве, в значительной мере состоит из непрофессионалов, для которых не депутатство, а другая, совмещаемая с ним работа служит основным источником дохода, отнимая большую часть рабочего времени (кстати, по данным нынешнего исследования, около 40 \% действующих депутатов занимают «параллельные» позиции, прежде всего в бизнесе).

Бюрократизация. Одна из тенденций рекрутирования региональной политической элиты - бюрократизация, выражающаяся в присутствии в депутатском корпусе выходцев из административных структур, чиновничества. Что вообще можно ожидать в плане вероятности вхождения администраторов в региональные легислатуры исходя, в частности, из характеристик политических режимов и систем субъектов РФ? Ситуация довольно неоднозначна. В современной России господствует субнациональный авторитаризм, в условиях которого региональные законодательные органы обычно играют слабую, второстепенную роль в политической жизни, не обладают существенной политической автономией и подчинены губернаторам [Golosov 2017; Шириков 2010]. Такой характер региональных легислатур может уменьшать привлекательность депутатской карьеры для администраторов, потому что переход в эти органы часто означает утрату реальной власти. Тем не менее депутатская должность, которая по сравнению с административным постом требует обычно меньше затрат времени и усилий 
и в то же время довольно престижна и в случае работы на постоянной основе высокооплачиваема, может служить синекурой или запасным аэродромом для чиновников, вынужденных по тем или иным причинам оставить свой пост. Избрание в парламент может быть для них не только формой почетной отставки или пенсии, но и возможностью передохнуть, осмотреться и дождаться в удобном кресле нового назначения. Кроме того, контроль губернатора над легислатурой может быть и позитивно связан с притоком чиновников в парламент. Рекрутирование на ключевые законодательные посты высокопоставленных региональных администраторов (а такие должности для них, разумеется, более привлекательны, чем рядовые депутатские позиции, в силу большей власти, престижа и дохода, которые они дают своим обладателям), лично знакомых главе региона и пользующихся его особым доверием, может выступать формой проявления и способом поддержания такого контроля. Как показывают исследования, практика избрания региональных чиновников руководящие посты в легислатурах весьма распространена [Богатырева 2012; Reuter, Turovsky 2014]. Вхождению чиновников в легислатуры может способствовать и специфика доминирующей в парламентах партии. «Единая Россия», которую нередко называют партией бюрократии, сильно зависит от административной власти разного уровня, будучи, по сути, ее «придатком» и инструментом бюрократического контроля над избирательным и законодательным процессом [Slider 2010: 262; Golosov 2011: 636-637; Makarenko 2012: 43; Roberts 2012: 230; Sakwa 2012: 320]. Такой характер этой партии должен проявляться в относительно широком присутствии выходцев из администрации в ее руководстве, избирательных списках и фракциях. Кстати, для самих депутатских фракций ЕР, постоянно взаимодействующих с региональными правительствами (как и для других фракций), бывшие высокопоставленные администраторы, обладающие знанием механизмов функционирования исполнительной власти и связями в ней, могут быть ценными кадрами. Вообще же надо отметить, что высокопоставленные чиновники располагают целым рядом ресурсов и преимуществ, делающих их сильными кандидатами в депутаты региональных законодательных собраний, а также Федерального Собрания РФ: властные полномочия и возможность их использования в избирательном процессе (так называемый «административный ресурс» играет важную роль на выборах в РФ [Нисневич, Савинцева 2012), известность в регионе, связи в элитных кругах. 
Приведенные выше таблицы 8 и 10 показывают, что лица с опытом работы в административных структурах составляют заметное меньшинство регионального депутатского корпуса. Мы видим, что примерно каждый девятый будущий депутат занимал административную позицию непосредственно перед вхождением в нынешний состав легислатуры. Примерно каждый восьмой-двенадцатый депутат был чиновником в 1995-2014 гг. Впрочем, картина значительно варьируется по регионам. Так, среди депутатов Ленинградской области и Дагестана соответственно 22 и 21 \% работали на административных позициях перед избранием в нынешний созыв легислатуры, тогда как в Новосибирской области таких было всего чуть более $2 \%$.

Причем следует подчеркнуть, что бюрократизация наиболее выражена среди высшей политической элиты (спикер, вице-спикеры, председатели комитетов). Так, 17 \% ее представителей (против $11 \%$ по всей совокупности) работали в административных структурах непосредственно перед избранием в нынешний созыв легислатуры. В некоторых случаях в депутатский корпус переходят действующие или бывшие региональные чиновники высшего ранга, занимающие посты спикеров. В частности, нынешней председатель Законодательного собрания Ростовской области в прошлом был заместителем губернатора региона, действующий спикер Костромской областной Думы - первым заместителем губернатора, а председатель Народного собрания Дагестана - председателем правительства республики. В свою очередь, председатель Калининградской областной Думы пятого и шестого созывов непосредственно перед избранием занимала пост заместителя председателя правительства Калининградской области по социальным вопросам.

В целом нужно отметить, что переход высокопоставленных региональных чиновников в легислатуры субъектов РФ, особенно на ключевые должности (как и вхождение депутатов в региональные администрации), может усиливать сплоченность и взаимопонимание этих двух фракций региональной элиты, способствовать их интеграции в единую, хотя и функционально и институционально дифференцированную властную элиту.

Плутократизащия. Одной из важнейших тенденций рекрутирования региональной политической элиты является плутократизация, приток в депутатский корпус выходцев из бизнеса и высшего руководства экономических (коммерческих) организаций различных форм собственности. Как показывают наши предыдущие исследования, зна- 
чение бизнеса в качестве поставщика региональных депутатов гораздо весомее его роли как источника рекрутирования высокопоставленных региональных чиновников [Быстрова и др. 2017]. Из таблиц 8 и 9 видно, что чуть менее 30 \% депутатов занимали ключевые позиции в экономических структурах непосредственно перед вхождением в нынешнюю должность, и у 40 \% с руководством предприятиями была связана предпредшествующая работа. Фактически бизнес поставляет больше депутатов, чем все остальные «внешние», т.е. находящиеся за пределами самой политической сферы, источники рекрутирования законодателей вместе взятые. Более того, если посмотреть на показатель предпредшествующей работы членов политической элиты, а также их работы в 1990-е - первой половине 2000-х годов, то окажется, что плутократизация является более выраженной тенденцией рекрутирования элиты, чем профессионализация. В частности, в 2000 г. только каждый восьмой нынешний парламентарий работал депутатом, тогда как $42 \%$ руководили различными предприятиями, и даже в 2008 г. большая доля нынешних законодателей были бизнесменами (41%), чем депутатами (28\%).

Впрочем, высшая политическая элита рекрутируется из бизнеса реже, чем рядовые депутаты: только 17 и 31 \% ее представителей занимали соответственно предшествующую и предпредшествующую позицию в высших органах управления коммерческих организаций.

Говоря об исторической динамике, нужно отметить, что доступные долговременные данные по четырем регионам (Санкт-Петербургу, Ленинградской, Ростовской и Калининградской областям) свидетельствуют о том, что уровень плутократизации региональной политической элиты немного возрос. Так, в 2005-2007 гг. 24 \%, в 2019 г. 27 \% депутатов непосредственно перед вхождением в нынешнюю должность были руководителями предприятий; в 2005-2007 гг. у 33 \%, в 2019 г. уже у 41 \% депутатов с руководством бизнесом была связана предпредшествующая работа.

Наконец, представляют также интерес и существенные региональные вариации плутократического рекрутирования политической элиты. Если судить по показателю предшествующей работы, то наиболее низкие уровни плутократизации демонстрирует депутатский корпус СанктПетербурга и Ленинградской области, где соответственно 11 и 19 \% парламентариев непосредственно перед избранием руководили экономическими структурами. Наиболее широко представлены прямые выходцы из бизнеса среди политической элиты Ростовской, Костромской 
и Калининградской областей, в которых соответственно 40,5, 37,5 и 37 \% народных избранников занимали ключевые позиции на предприятиях, перед тем как занять нынешнюю должность.

Широкое присутствие бизнесменов в законодательных органах субъектов РФ (а также среди представителей регионов в Федеральном Собрании) в общем неудивительно. Говоря о его причинах, следует прежде всего отметить, что в условиях, когда государство оказывает значительное влияние на процесс накопления капитала, что характерно для всех современных капиталистических обществ, бизнес-структуры способны извлекать существенные выгоды из политических связей, возникающих, в частности, при занятии их руководителями должностей в государственном аппарате, включая органы представительной власти. Исследования показывают, что эти связи могут быть особенно выгодны в странах с относительно неразвитыми рыночными институтами, слабой правовой системой (и незащищенностью прав собственности) и высоким уровнем коррупции [Boubakri et al. 2008: 1; Goldman, Rocholl, So 2009: 2236; Faccio 2010; Chen et al. 2011], как постсоветская Россия. Также некоторые авторы [Gehlbach, Sonin, Zhuravskaya 2010] полагают, что политические связи более выгодны при недемократических режимах, когда вследствие слабой подотчетности выборных чиновников избирателям у бизнеса больше возможностей подчинить политику своим интересам (хотя эта точка зрения оспаривается [Szakonyi 2016]). Вообще, по распространенному мнению ([The Economist 2014]; см. также: [Волкова 2016]), в России сложился «кумовской капитализм», при котором связи с государственной властью являются важнейшим, первостепенным условием успешного ведения бизнеса. Касаясь, в частности, тех выгод, которые бизнесу может принести депутатский мандат, надо отметить, что он не только позволяет его представителям участвовать в законотворческом процессе в интересах своей фирмы, отрасли или делового сообщества в целом, но и, что важнее, облегчает доступ к чиновникам, принимающим основные решения в области экономической политики, и другим влиятельным персонам. Как показало исследование, проведенное Д. Жакони [Szakonyi 2018], победа выходца из руководства фирмы на выборах в региональную легислатуру оказывает существенное позитивное влияние на ее доходы и прибыли, прежде всего потому, что расширяет доступ к бюрократам. Впрочем, интерес бизнеса к депутатскому мандату необязательно ограничивается лоббистской составляющей, существенную роль могут играть и другие 
мотивы, в частности соображения престижа и статуса, стремление к власти и самореализации и пр. Для бизнесменов может быть важна и неприкосновенность, которой пользуются депутаты ГД члены СФ, особенно учитывая то, что накопление капитала в постсоветский период часто велось с нарушением законов. Нужно также отметить, что в некоторых случаях неудачи в бизнесе способны мотивировать предпринимателей к переходу на постоянную работу в региональные легислатуры и ФС, поскольку зарплата депутата-профессионала довольно высока.

Конечно, заинтересованность бизнесменов в получении депутатского мандата не следует преувеличивать. Избирательная кампания и депутатская деятельность требуют значительных ресурсов, включая прежде всего деньги и время, которые отвлекаются от собственно экономической деятельности. Кроме того, публичность может повлечь за собой определенные риски, и нередко бизнесмены ее избегают, придерживаясь принципа «деньги любят тишину». Чтобы отстаивать свои интересы, им необязательно самим избираться в представительные органы, они могут использовать с этой целью других депутатов, финансируя их избирательные кампании или просто подкупая. Но всегда существует вероятность оппортунизма таких ставленников, которые могут в силу разных причин отказаться от выполнения своих обязательства перед спонсорами. Причем, по мнению Д. Жакони, эта проблема стоит особенно остро в России, где политические партии, которые могли бы дисциплинировать депутатов, заставляя их выполнять обещания, данные финансирующим их бизнесменам, довольно слабы [Szakonyi 2016]. Поэтому собственное присутствие капиталистов в органе представительной власти может быть более надежной и предпочтительной стратегией. Важной предпосылкой выбора капиталистами стратегии прямого, личного, а не только опосредованного присутствия в органах представительной власти, вероятно, является институциональный дизайн региональных парламентов. Как уже говорилось, в России, включая исследуемые регионы, во многих таких органах значительная, даже преобладающая часть депутатов вправе работать на непостоянной основе, предполагающей возможность совмещения депутатства с основной работой, например в бизнесе. Таким образом, бизнесмены могут занимать депутатские посты, не покидая командных высот в экономических структурах, что важно с точки зрения как сохранения высоких доходов, так и контроля над капиталом, прежде 
всего для наемных менеджеров. В этой связи следует отметить, что ключевая должность в бизнесе была наиболее распространенной «параллельной», т.е. совмещаемой с депутатством, позицией (почти в трех четвертях случаев). Отсутствие института парламентского совместительства, вероятно, ослабило бы интерес многих представителей бизнеса к депутатским мандатам в силу высоких издержек смены работы. В этом смысле не случайно, что, как уже отмечалось, плутократизация сильнее выражена среди рядовых депутатов, чем у парламентариев, занимающих высшие позиции в легислатуре, которые чаще всего предполагают занятость на постоянной, профессиональной основе. Также объяснимо и то, что наименьший уровень плутократизации характерен для парламента Санкт-Петербурга, где все депутаты должны работать на профессиональной основе и не вправе совмещать свои обязанности с коммерческой деятельностью.

В плане ресурсов и преимуществ, которые можно мобилизовать для успешной избирательной кампании, бизнесмены, прежде всего крупные, значительно превосходят большинство других социальнопрофессиональных групп. Основной ресурс, находящийся в распоряжении капиталистов, - это, конечно, финансовые средства, которые важны на выборах как по одномандатным округам, так и по партийным спискам. Избирательные кампании требуют больших затрат [Барсукова, Звягинцев 2006], и от поддержки бизнес-структур, несмотря на государственное финансирование, существенно зависят российские политические партии [Wilson 2007; Коргунюк 2010; Шлейнов 2015; Hutcheson 2012]. Так, согласно финансовым отчетам «Единой России», пожертвования, в основном юридических лиц, составили более половины поступлений на осуществление уставной деятельности в 2016 г., когда проводились последние выборы в ГД, и более трети в 2018 г. [Сводный финансовый отчет за 2016 г. ...; Сводный финансовый отчет за 2018 г. ...]. Говоря о политических ресурсах бизнеса, не следует также забывать и о средствах массовой информации, которыми нередко владеют предприниматели. Также важно отметить, что под властью капиталистов находятся более или менее крупные трудовые коллективы, и зависимость на рабочем месте, экономическая зависимость благоприятное условие для оказания политического влияния и давления со стороны работодателя (его формы могут быть различными - агитация на предприятии, организованный подвоз рабочих на избирательные участки, голосование на работе по открепительным удостоверени- 
ям и пр.) (см., например: [Golosov 2013: 477]). Недавнее исследование показало, что в России работодатели, особенно фирмы с иммобильными активами и компании, зависимые от государства, широко используют экономическое принуждение для политической мобилизации работников [Frye, Reuter, Szakonyi 2014]. Кроме того, руководители крупнейших предприятий, являющихся основными работодателями и налогоплательщиками в городах и регионах (а также иногда имеющих на своем балансе крупные учреждения социальной сферы), обладают значительной структурной властью. Объективная зависимость благосостояния избирателей и доходов бюджета от успешной работы таких предприятий облегчает их руководству представление своих частных интересов в качестве всеобщих, что является важной предпосылкой успешной предвыборной агитации. Наконец, стоит также добавить, что находящиеся в многообразной зависимости от крупного капитала региональные власти могут оказывать административную поддержку кандидатам-бизнесменам.

Каковы политические последствия высокого уровня плутократизации региональной законодательной элиты, доминирования выходцев из бизнеса в легислатурах субъектов РФ? Эта тенденция может иметь противоречивые следствия. Как отмечает Д. Жакони, «в местах с низким человеческим капиталом экономические элиты могут быть единственными индивидами, способными править. Их опыт руководства фирмами частного сектора может выразиться в превосходящих навыках управления бюрократическими кадрами, ведения переговоров по законодательству и реагирования на реальные проблемы» [Szakonyi 2016: 168]. Плутократизация депутатского корпуса способствует тому, чтобы интересы бизнеса или класса капиталистов (прежде всего такие, как обеспечение благоприятного инвестиционного климата и экономического роста) занимали привилегированное, приоритетное место в его политике и, более того, отождествлялись парламентариями с интересами регионального сообщества в целом. Рост экономики способен приносить выгоды не только бизнесу, но и более широким слоям населения. В то же время тесная связь региональной политической элиты с бизнесом может существенно ограничивать ее способность выступать в качестве субъекта инициирования и осуществления прогрессивных социальных реформ, отвечающих интересам большинства жителей региона, как и вообще любой политики, могущей, хотя бы в краткосрочном плане, ухудшить «деловой климат». Не менее важно то, что 
конкретные бизнесмены склонны подчинять политику своим особым (special) интересам в ущерб интересам не только большинства населения региона, но нередко и регионального делового сообщества в целом, стремясь к извлечению ренты и собственному обогащению за счет использования публичных ресурсов. В связи с этим нужно отметить, что широкое присутствие бизнесменов в депутатском корпусе может способствовать дезинтеграции региональной политической элиты, раздираемой противоречиями и соперничеством различных особенных капиталистических интересов.

Социальная закрытость. Региональной политической элите свойственна высокая степень социальной закрытости с точки зрения бассейна ее рекрутирования, который довольно узок. Как показывает проведенный анализ, почти 90 \% законодателей непосредственно перед вхождением в нынешнюю должность (и более 80 \% перед вхождением в должность, предшествующую нынешней) занимали позиции депутатов, администраторов или бизнесменов, т.е. относились к тем или иным властным группам, нередко входя в состав региональной властной элиты.

На этом фоне мы обнаруживаем почти полное отсутствие в региональной политической элите выходцев из низших классов. Хотя рабочие и крестьяне составляют значительную долю избирателей, для них доступ в депутатский корпус фактически закрыт. Как видно из таблицы 10, в 1993 г. всего 1 \% депутатов регионального уровня были рабочими или крестьянами по характеру своей работы, причем такие персоны встречаются в депутатском корпусе только четырех регионов из десяти (но, что интересно, среди высшей политической элиты их было больше 3 \%). В последующие годы доля будущих парламентариев, занимавших «рабоче-крестьянское» положение в социально-профессиональной структуре, также не превышала 1 \%, к 2004 г. она фактически сократилась до нуля. Всего один депутат был избран в легислатуру непосредственно с такой позиции. В этом смысле постсоветские региональные легислатуры существенно отличаются от функционирующих в советское время и сформированных по номенклутарно-квотному принципу Советов народных депутатов, где рабочие и другие члены подчиненных классов были широко представлены. Вообще их отсутствие в современных легислатурах неудивительно, учитывая прежде всего тот факт, что они слабо обеспечены ресурсами и преимуществами, важными для политической карьеры, включая финансовые средства, культурный капитал, свободное время, необходимое для занятия политикой, организа- 
ционные навыки. В условиях острой конкуренции за довольно малочисленные (а нынешние региональные парламенты гораздо компактнее бывших Советов), но весьма привлекательные места региональных законодателей и представителей субъектов РФ в Федеральном Собрании у выходцев из малоресурсных групп мало шансов попасть в легислатуры. Западный опыт показывает, что подобная ситуация отчасти исправлялась коллективными действиями рабочих, их организацией в профсоюзы и партии, что позволяло им консолидировать скудные индивидуальные ресурсы и более успешно участвовать в политике. Массовые левые партии, тесно связанные с рабочим движением, в определенной степени служили социальными и политическими лифтами для рабочих, и в некоторых странах, где такие партии были электорально успешны (например, лейбористы в Великобритании), присутствие рабочих в общенациональном парламенте временами было значительным [Norris, Lovenduski 1995: 97; Cotta, Verzichelli 2007: 431]. Однако в постсоветской России такая движущая сила демократизации социально-классового состава легислатур, как тесно связанные с рабочим движением, электорально успешные и по-настоящему массовые левые партии, отсутствует. В частности, КПРФ по своему составу преимущественно партия пенсионеров, а не рабочих (см., например: [Облик партии ... 2013]).

Следует также отметить, что не только рабочие и крестьяне, но и группы, занимающие средние, промежуточные позиции в социально-профессиональной структуре также очень скромно представлены в современной региональной политической элите России. Так, в целом по десяти исследуемым регионам только 1-2 \% депутатов занимали должности специалистов различных предприятий и организаций в 2000-2014 гг. (в постсоветский период больше всего специалистов среди нынешних депутатов было в 1993 г. - 5 \%). Чуть выше доля выходцев из сферы науки, культуры, образования и здравоохранения, но и она невелика. В 1993 гг. в этой области работало 11 \% нынешних депутатов, но в 2014 г. - всего 2 \% народных избранников (и 3 \% будущих депутатов было рекрутировано в нынешний созыв легислатуры непосредственно из этой сферы). Кроме того, надо отметить, что среди представителей указанных отраслей обычно преобладают топменеджеры соответствующих, в основном бюджетных, организаций (ректоры вузов, главные врачи больниц, директора школ и их заместители) и мало рядовых врачей, преподавателей и учителей. В региональ- 
ном разрезе относительно широко данная социально-профессиональная категория представлена в Хабаровском крае.

Высокий уровень социально-классового неравенства в доступе к позициям политической власти, узость источников рекрутирования региональной политической элиты, члены которой являются преимущественно выходцами из высокостатусных социально-профессиональных групп, может иметь важные следствия. С одной стороны, социальная однородность депутатского корпуса, отсутствие социально-классовой поляризации бассейна его рекрутирования (подавляющее доминирование в нем выходцев из различных властных групп, «начальства», высшего руководства разнообразных, часто крупных и крупнейших по региональным меркам организаций) могут усиливать его сплоченность, интеграцию. С другой стороны, тот факт, что социально-профессиональный состав политической элиты довольно слабо отражает структуру подвластного ей населения, что в легислатурах члены подчиненных социальных классов представлены крайне скромно или вовсе отсутствуют, способствует тому, чтобы в региональной политике интересы этих групп ущемлялись, приносились в жертву интересам социально-привилегированного меньшинства. Наконец, глубокое расхождение социально-структурных характеристик политической элиты и населения, ее социологически нерепрезентативный характер могут подрывать ее легитимность в глазах граждан (которая, как отмечал Р. Патнем [Putnam 1976: 44], частично основывается на представлении о равенстве возможностей), усиливать отчуждение между властью и обществом.

\section{ЗАКЛЮЧЕНИЕ}

Исследование бассейна рекрутирования и карьерных путей региональной политической элиты позволило выявить ряд важных тенденций.

Во-первых, существенное меньшинство депутатского корпуса укоренено в советской номенклатуре, однако доля выходцев из партийных, советских и комсомольских органов снижается, что связано с постепенным старением номенклатурных кадров и их выбытием из элиты.

Во-вторых, среди депутатов получил определенное распространение опыт службы в силовых ведомствах, хотя его присутствие сильно варьируется по регионам и характерно только для меньшинства.

В-третьих, весьма заметна тенденция профессионализации депутатского корпуса и его преемственности от созыва к созыву. Однако 
профессионализация сильно сдерживается тем фактом, что большинство законодателей работают на непостоянной основе, совмещая депутатство с основной работой.

В-четвертых, выражена бюрократизация состава региональных легислатур, особенно их руководящего слоя, в котором много выходцев из административных органов, прежде всего регионального уровня. Рекрутирование на руководящие законодательные посты высокопоставленных чиновников администраций субъектов РФ может рассматриваться как форма проявления и способ контроля губернаторов над легислатурами.

В-пятых, одной из важнейших тенденций рекрутирования политической элиты является плутократизация, т.е. приток представителей бизнеса в легислатуры, что, вероятно, отражает и закрепляет «кумовской» характер российского капитализма, при котором связи с государственной властью являются важнейшим условием накопления капитала. Плутократизация политической элиты - важный показатель и фактор ее интеграции с экономически господствующим классом, что ведет к дружественной по отношению к его интересам политике.

Наконец, депутатский корпус отличает высокая степень социальной закрытости. В нем подавляющим образом доминируют выходцы из «руководящей страты», почти нет персон, занимавших «рабоче-крестьянские» позиции в постсоветский период, и слабо представлены выходцы из средних, промежуточных социально-профессиональных категорий. Социологическая непредставительность региональной политической элиты может подрывать ее легитимность.

\section{Литература}

Барсукова С., Звягинцев В. Механизм «политического инвестирования», или Как и зачем бизнес участвует в выборах и оплачивает партийную жизнь // Политические исследования. 2006. № 2. С. 110-121.

Богатырева Л.В. Механизмы рекрутирования глав региональных законодательных собраний (на примере регионов ЦФО) // Политическая наука. 2012. № 1. С. 175-189.

Буренкова Э.Э. Трансформации общества и внутренние характеристики элитных групп: об изучении элитных групп // Мир России. 1995. № 3-4. С. 3-24.

Быстрова А.С. Влияние социального контекста на построение карьерных траекторий: карьеры представителей различных политических поколений региональных административных элит Российской Федерации // Власть и элиты. Т. 4 / отв. ред. А.В. Дука. СПб.: Интерсоцис, 2017. С. 170-203. 
Быстрова А.С., Даугавет А.Б., Дука А.В., Тев Д.Б. Региональные властные группы: основные социально-структурные характеристики и роль в развитии современного российского общества // Власть и элиты. Т. 4 / отв. ред. А.В. Дука. СПб.: Интерсоцис, 2017. С. 147-169.

Быстрова А., Дука А., Колесник Н., Невский А., Тев Д. Российские региональные элиты: инновационный потенциал в контексте глобализации // Глобализация в российском обществе: сб. науч. трудов / отв. ред. И.И. Елисеева. СПб.: Нестор-История, 2008. С. 99-243.

Гаман-Голутвина О.В. Политические элиты России. Вехи исторической эволюции. М.: РОССПЭН, 2006. 446 с.

Григорьева М.В. Участие региональных и муниципальных депутатов в выборах законодательных собраний субъектов РФ // Вестник Пермского университета. Серия: Политология. 2012. № 3. С. 13-29.

Гудков Л. Перерождение коммунистической номенклатуры // Россия на рубеже веков. 1991-2011 / ред. и сост. А. Зубов, В. Страда. М.: РОССПЭН, 2011. C. 116-133.

Дука А.В. К вопросу о милитократии: силовики в региональных властных элитах // Властные структуры и группы доминирования: материалы X всерос. семинара «Социологические проблемы власти в условиях российской трансформации» / под ред. А.В. Дуки. СПб.: Интерсоцис, 2012. С. 94-20.

Региональные элиты Северо-Запада России: политические и экономические ориентации / под ред. А.В. Дуки. СПб.: Алетейя, 2001. 352 с.

Коргунюк Ю.Г. Финансирование партий в постсоветской России: между бизнесом и властью // Полития: Анализ. Хроника. Прогноз (Журнал политической философии и социологии политики). 2010. № 3-4 (58-59). С. 87-120.

Крыштановская О. Трансформация старой номенклатуры в новую российскую элиту // Общественные науки и современность. 1995. № 1. С. 51-65.

Крыштановская О. Анатомия российской элиты. М.: Захаров, 2004. 384 с.

Крыштановская О. Элита в сетях: новые формы обратной связи в цифровую эпоху // Цифровая социология. 2019. №2 (2) С. 4-11. https://doi. org/10.26425/2658-347X-2019-2-411.

Куколев И.В. Трансформация политических элит в России // Общественные науки и современность. 1997. № 4. С. 82-91.

Латыпов Р.Ф. Эволюция политико-административных элит в постсоветской России: кросс-региональный анализ // Социология власти. 2009. № 6. С. 110-118.

Медведев Ю.С. Профессиональный статус как фактор успеха на региональных выборах // Полития: Анализ. Хроника. Прогноз (Журнал политической философии и социологии политики). 2010. № 2 (57). С. 75-90.

Пихоя Р.Г. Как власть обменяли на собственность // Социология власти. 2011. № 11. С. 5-11.

Понеделков А.В. Политическая элита: генезис и проблемы ее становления в России. Ростов н/Д.: Изд-во СКНЦ ВШ, 1995. 208 с. 
Региональные элиты Северо-Запада России: политические и экономические ориентации / Под ред. А.В. Дуки. СПб.: Алетейя, 2001. 352 с.

Сафронов B.В. Консолидация авторитаризма или демократизация: поддержка путинского режима элитой Санкт -Петербурга // Условия и возможности консолидации российского общества: сб. науч. трудов СИ РАН / отв. ред. А.В. Дука, И.И. Елисеева. СПб.: Нестор-История, 2010. С. 30-110.

Селезнев А.В., Рогозарь-Колпакова И.И., Филистович Е.С., Трофимова В.В., Добрьнина Е.П., Стрелеи, И.Э. Российская политическая элита: анализ с точки зрения концепции человеческого капитала // Политические исследования. 2010. № 4. С. $90-106$.

Слепиов Н.С., Куколев И.В., Рьскова Т.М. Новая легитимность региональных лидеров // Социология власти. 1997. № 3. С. 5-23.

Шириков А.С. Анатомия бездействия: политические институты и конфликты в бюджетном процессе регионов России. СПб.: Изд-во Европейского университета в Санкт-Петербурге, 2010. 276 с.

Baturo A. Cursus Honorum: Personal Background, Careers and Experience of Political Leaders in Democracy and Dictatorship. New Data and Analyses // Politics and Governance. 2016. Vol. 4, issue 2. P. 138-157. https://doi. org/10.17645/pag. $\mathrm{v} 4 \mathrm{i} 2.602$.

Best H., Cromwell V., Hausmann C., Rush M. The Transformation of Legislative Elites: The Cases of Britain and Germany since the 1860s. // Journal of Legislative Studie. 2001. № 7 (3). P. 65-91. https://doi.org/10.1080/714003883.

Bianco W.T. Last Post for “The Greatest Generation”: The Policy Implications of the Decline of Military Experience in the U.S. Congress // Legislative Studies Quarterly. 2005. № 30 (1). P. 85-102. https://doi.org/10.3162/036298005X201464.

Black G.S. A Theory of Political Ambition: Career Choices and the Role of Structural Incentives // American Political Science Review. 1972 . № 66 (1). P. 144-159. https://doi.org/10.2307/1959283.

Boubakri N., Guedhami O., Mishra D., Saffar W. (2008) Political Connections and the Cost of Equity Capital. 2008. URL: http://citeseerx.ist.psu.edu/viewdoc/dow nload?doi=10.1.1.175.6368\&rep=rep1\&type=pdf] (дата обращения: 16.04.2017).

Carnes N. Does the Numerical Underrepresentation of the Working Class in Congress Matter? // Legislative Studies Quarterly. 2012. № 37 (1). P. 5-34. https:// doi.org/10.2307/41719830.

Carnes N., Lupu N. Rethinking the Comparative Perspective on Class and Representation: Evidence from Latin America // American Journal of Political Science. 2015. № 59 (1). P. 1-18. https://doi.org/10.1111/ajps.12112.

Chaisty P. The Preponderance and Effects of Sectoral Ties in the State Duma // Europe-Asia Studie. 2013. № 65 (4). P. 717-736. https://doi.org/10.1080/09668136.2 013.767605 .

Chen C.J.P., Li Z., Su X., Sun Z. Rent-seeking incentives, corporate political connections, and the control structure of private firms: Chinese evidence // Journal 
of Corporate Finance. 2011. № 17 (2). P. 229-243. https://doi.org/10.1016/j. jcorpfin.2010.09.009.

Cotta M., Verzichelli L. Paths of Institutional Development and Elite Transformations // Democratic Representation in Europe: Diversity, Change, and Convergence / eds. M. Cotta, H. Best. Oxford: Oxford University Press, 2007. P. 417-473.

Derge D.R. The Lawyer as Decision-Maker in the American State Legislature // Journal of Politics. 1959. № 21 (3). P. 408-433. https://doi.org/10.2307/2127322.

Dyer J.A. Do Lawyers Vote Differently? A Study of Voting on No-Fault Insurance // Journal of Politics. 1976. № 38 (2). P. 452-456.

Edinger $M$. Elite Formation and Democratic Elitism in Central and Eastern Europe: A Comparative Analysis // Democratic Elitism: New Theoretical and Comparative Perspectives / eds. H. Best, J. Higley. Leiden: Brill, 2010. P. 129-151.

Edinger L., Searing D. Social Background in Elite Analysis: A Methodological Inquiry // American Political Science Review. 1967. № 61 (2). P. 428-445. https:// doi.org/10.2307/1953255.

Erikson R.S. The Advantage of Incumbency in Congressional Elections // Polity. 1971. № 3 (3). P. 395-405.

Faccio M. Differences between Politically Connected and Nonconnected Firms: A Cross-Country Analysis // Financial Management. 2010. № 39 (3). P. 905-928. https://doi.org/10.1111/j.1755-053X.2010.01099.x.

Frye T., Reuter O.J., Szakonyi D. Political Machines at Work Voter Mobilization and Electoral Subversion in the Workplace // World Politics. 2014. № 66 (2). P. 195228. https://doi.org/10.1017/S004388711400001X.

Gehlbach S., Sonin K., Zhuravskaya E. Businessman Candidates // American Journal of Political Science. 2010. № 54 (3). P. 718-736. https://doi. org/10.1111/j.1540-5907.2010.00456.x.

Goldman E., Rocholl J., So J. Do Politically Connected Boards Affect Firm Value? // Review of Financial Studies. 2009. № 22 (6). P. 2331-2360. https://doi.org/10.1093/ rfs/hhn088.

Golosov G.V. The Regional Roots of Electoral Authoritarianism in Russia // Europe-Asia Studies. 2011. № 63 (4). P. 623-639. https://doi.org/10.1080/09668136. 2011.566427.

Golosov G.V. Machine Politics: The Concept and Its Implications for Post-Soviet Studies // Demokratizatsiya. The Journal of Post-Soviet Democratization. 2013. № 21 (4). P. 459-480.

Golosov G.V. Legislative Turnover and Executive Control in Russia's Regions (2003-2014) // Europe-Asia Studies. 2017. № 69 (4). P. 553-570. https://doi.org/10. 1080/09668136.2017.1337871.

Green J.J., Schmidhauser J.R., Berg L.L., Brady D. Lawyers in Congress: A New Look at Some Old Assumptions // Western Political Quarterly. 1973. № 26 (3). P. 440-452. https://doi.org/10.1177/106591297302600304. 
Hall R.L., van Houweling R.P. Avarice and Ambition in Congress: Representatives' Decisions to Run or Retire from the U.S. House // American Political Science Review. 1995. № 89 (1). P. 121-136. https://doi. org/10.2307/2083079.

Hansen E.R., Carnes N., Gray V. What Happens When Insurers Make Insurance Laws? State Legislative Agendas and the Occupational Makeup of Government // State Politics \& Policy Quarterly. 2019. № 19 (2). P. 155-179. https://doi. org/10.1177/1532440018813013.

Herrick R., Moore M.K Political Ambition's Effect on Legislative Behavior: Schlesinger's Typology Reconsidered and Revised // Journal of Politics. 1993. № 55 (3). P. 765-76. https://doi.org/10.2307/2132000.

Hutcheson D.S. Party Finance in Russia // East European Politics. 2012. № 28 (3). P. 267-282. https://doi.org/10.1080/21599165.2012.689978.

Ilonszki G., Edinger M. MPs in Post-Communist and Post-Soviet Nations: A Parliamentary Elite in the Making // Journal of Legislative Studies. 2007. № 13 (1). P. 142-163. https://doi.org/10.1080/13572330601165436.

Kerbo H.R., Fave L.R.D. The Empirical Side of the Power Elite Debate: an Assessment and Critique of Recent Research // Sociological Quarterly. 1979. № 20 (1). P. 5-22. https://doi.org/10.1111/j.1533-8525.1979.tb02181.x.

Kim C.L., Patterson S.C. Parliamentary Elite Integration in Six Nations // Comparative Politics. 1988. № 20 (4). P. 379-399. https://doi.org/10.2307/421935.

Lawless J.L. Becoming a Candidate: Political Ambition and the Decision to Run for Office. Cambridge: Cambridge University Press, 2012. 302 p.

Makarenko B.I. The Post-Soviet Party of Power: United Russia in Comparative Context // Russian Social Science Review. 2012. № 53 (4). P. 27-56. https://doi.org/ 10.1080/10611428.2012.11065482.

Matland R.E., Studlar D.T. Determinants of Legislative Turnover: A CrossNational Analysis // British Journal of Political Science. 2004. № 34 (1). P. 87-108. https://doi.org/10.1017/S000712340300036X.

Matthews D.R. United States Senators and the Class Structure // Public Opinion Quarterly. 1954. № 18 (1). P. 5-22. https://doi.org/https://doi.org/10.1086/266482.

Matthews D.R. Legislative Recruitment and Legislative Careers // Legislative Studies Quarterly. 1984. № 9 (4). P. 547-585. https://doi.org/10.2307/439635.

Nicholls K. The Dynamics of National Executive Service. Ambition Theory and the Careers of Presidential Cabinet Members // Western Political Quarterly. 1991. № 44 (1). P. 149-172. https://doi.org/10.2307/448752.

Norris P., Lovenduski J. Political Recruitment: Gender, race and class in the British parliament. Cambridge: Cambridge University Press, 1995. 320 p.

Öhberg P. Ambitious Politicians. The Implications of Career Ambition in Representative Democracy. Lawrence: University Press of Kansas, 2017. 224 p.

Putnam R.D. The Comparative Study of Political Elites. Englewood Cliffs, N.J.: Prentice-Hall, 1976. 246 p. 
Reuter O.J., Turovsky R. Dominant party rule and legislative leadership in authoritarian regimes // Party Politics. 2014. № 20 (5). P. 663-674. https://doi. org/10.1177/1354068812448689.

Roberts S.P. United Russia and the Dominant-Party Framework: Understanding the Russian Party of Power in Comparative Perspective // East European Politics. 2012. № 28 (3). P. 225-240. https://doi.org/10.1080/21599165.2012.684754.

Sakwa R. Party and Power: Between Representation and Mobilisation in Contemporary Russia // East European Politics. 2012. № 28 (3). P. 310-327. https:// doi.org/10.1080/21599165.2012.683784.

Schlesinger J.A. Ambition and Politics. Political Careers in the United States. Chicago: Rand McNally and Company, 1966. 226 p.

Shabad G., Slomczynski K.M. The Emergence of Career Politicians in PostCommunist Democracies: Poland and the Czech Republic // Legislative Studies Quarterly. 2002. № 27 (3). P. 333-359. https://doi.org/10.2307/3598567.

Slider D. How United is United Russia? Regional Sources of Intra-party Conflict // Journal of Communist Studies and Transition Politics. 2010. № 26 (2). P. 257-275. https://doi.org/10.1080/13523271003712617.

Szakonyi D. Renting Elected Office: Why Businesspeople Become Politicians in Russia. Submitted in partial fulfillment of the requirements for the degree of Doctor of Philosophy in the Graduate School of Arts and Sciences. Columbia University. 2016. URL: https://academiccommons.columbia.edu (дата обращения: 22.12.2017).

Szakonyi D. Private Sector Policymaking: Business Background and Politicians' Behavior in Office. 2017. URL: https://papers.ssrn.com/sol3/papers.cfm?abstract_ $\mathrm{id}=2844901$ (дата обращения: 22.12.2017).

Szakonyi D. Businesspeople in Elected Office: Identifying Private Benefits from Firm-Level Returns // American Political Science Review. 2018. № 112 (2). P. 322-338. https://doi.org/10.1017/S0003055417000600.

The Economist. Planet Plutocrat: Our Crony-Capitalism Index. 2014. URL: http:// www. economist.com/news/international/21599041-countries-where-politicallyconnectedbusinessmen-are-most-likely-prosper-planet (дата обращения: 17.12.2014).

Vercesi M. Approaches and lessons in political career research: Babel or pieces of patchwork? // Revista Española de Ciencia Política. 2018. № 48. P. 183-206. https:// doi.org/10.21308/recp.48.07.

Wilson K. Party Finance in Russia: Has the 2001 Law «On Political Parties» Made a Difference? // Europe-Asia Studies. 2007. №59 (7). P. 1089-1113. https://doi. org/10.1080/09668130701607094

Witko C., Friedman S. Business Backgrounds and Congressional Behavior // Congress \& the Presidency. 2008. № 35 (1). P. 71-86. https://doi. org/10.1080/07343460809507652. 


\section{Источники}

Волкова О. Ученые назвали политические связи главным источником богатства в России // RBC.ru. URL: http://www.rbc.ru/economics/11/03/2016/56e2a 1ac9a7947f56 bedc71a (дата обращения: 17.09.2016).

Закон Костромской области от 8 июня 2009 года № 486-4-3КО «О статусе депутата Костромской областной Думы» (с изм. на 22 мая 2018 г.). URL: http:// docs.cntd.ru/document/895208812 (дата обращения: 26.06.2018).

Закон Республики Дагестан от 13 июля 1995 года № 1 «О статусе депутата Народного Собрания Республики Дагестан». URL: http://docs.cntd.ru/ document/802037539 (дата обращения: 26.06.2018).

Нисневич Ю.А., Савинцева М.И. Отчет Transparency International Russia. Использование административного ресурса на выборах депутатов Государственной Думы РФ 4 декабря 2011 года. URL: http://files.golos.org/docs/5375/ original/5375-glava-6.doc?1328118890 (дата обращения: 16.09.2014).

Новосибирское заксобрание будет платить зарплату еще одному депутату // Коммерсантъ. 28.02.2018. URL: https://www.kommersant.ru/doc/3560083 (дата обращения: 28.02.2018).

Облик партии перед XV съездом. По страницам газеты «Правда» // Правда. 2013-02-22. URL: https://kprf.ru/party-live/cknews/115734.html (дата обращения: 29.01.2015).

Романовский Р. Депутаты-прогульщики: как работают депутаты Облдумы в цифрах // Rugrad.eu. 23 февраля 2018. URL: https://rugrad.eu/interview/1023744/ smi/ (дата обращения: 23.02.2018).

Сводный финансовый отчет за 2016 год политической партии «Всероссийская политическая партия «Единая Россия» // Сайт ЦИК РФ. URL: http://www. cikrf.ru/politparty/finance/svodn_otchet_16.php (дата обращения: 28.02.2018).

Сводный финансовый отчет за 2018 год политической партии «Всероссийская политическая партия «Единая Россия» // Сайт ЦИК PФ. URL: http://www. cikrf.ru/politparty/finance/svodn_otchet_18.php (дата обращения: 26.12.2019).

Только половина депутатов Хабаровской краевой думы будут получать зарплату // Дебри-ДВ. 19.09.2014. URL: http://www.debri-dv.ru/m/article/10014/ tolko_polovina_deputatov_habarovskoy_kraevoy_dumy_budut_poluchat_zarplatu (дата обращения 19.09.2017).

Ульянова Ж. В Мосгордуме на постоянной основе будут работать 18 депутатов // RBC.ru. URL: https://www.rbc.ru/politics/22/09/2014/570422799a794760d 3d41a78 (дата обращения: 22.09.2014).

Шлейнов Р. Кто и почему пожертвовал «Единой России» 6 млрд руб. // Ведомости. URL: http:// www.vedomosti.ru/newspaper/articles/2010/12/20/dengi_ partii (дата обращения: 20.12.2015). 


\title{
REGIONAL POLITICAL ELITE: CAREERS AND POOL OF RECRUITMENT
}

\section{A. Bystrova, A. Daugavet, A. Duka ${ }^{1}$, N. Kolesnik, A. Nevskiy, D. Tev}

\author{
Sociological Institute of the Russian Academy of Sciences - \\ a branch of the Federal Center of Theoretical and Applied Sociology \\ of the Russian Academy of Sciences, \\ St. Petersburg, Russia
}

Citation: Bystrova A., Daugavet A., Duka A., Kolesnik N., Nevskiy A., Tev D. Regional'naya politicheskaya elita: basseyn rekrutirovaniya i kar'yera [Regional political elite: careers and pool of recruitment]. Vlast' $i$ elity [Power and Elites], 2020, 7 (1): 76-122. (In Russian)

DOI: https://doi.org/10.31119/pe.2020.7.1.4

Abstract. The article presents an analysis of the recruitment pool and career paths of regional politicians. The empirical basis of the study is the biographical database of the political elite of 10 subjects of the Russian Federation (deputies of regional legislatures, as well as deputies of the State Duma and members of the Federation Council representing the regions). The study was carried out using the structural-biographical method, in which the structure of the regional elite groups is studied in connection with the biography of the people composing these groups. As a result, a number of trends in the recruitment of the political elite were identified. The study showed that a significant minority of the regional deputy corps is rooted in the Soviet nomenclature, and also some politicians have experience in serving in law enforcement agencies. There is a noticeable trend of the professionalization of the deputy corps, which, however, is strongly restrained by the fact that most legislators work on the non-full time basis. The bureaucratization of the composition of regional legislatures is expressed, especially of their leading stratum, in which there are many entrants from administrative bodies, primarily of the regional level. One of the most important trends in the recruitment of the political elite is plutocratization, that is, the influx of business representatives into the legislature. The deputy corps is distinguished by a high degree of social closure: it is dominated by people from the "managing stratum", there are almost no people who occupied "workers'-and-peasants" positions in the post-Soviet period, and people from middle, intermediate social and professional categories are poorly represented.

${ }^{1}$ Corresponding author. E-mail: alexander-duka@yandex.ru. 
Keywords: regional political elites, deputies, politicians, recruitment, careers, biographies, plutocratization, bureaucratization, recruitment pool.

\section{References}

Barsukova S., Zvjagincev V. () Mehanizm «politicheskogo investirovanija», ili kak i zachem biznes uchastvuet v vyborah i oplachivaet partijnuju zhizn' [The mechanism of "political investment", or how and why business participates in the elections and pays for party life]. Politicheskie issledovanija [Political Studies], 2006, 2, pp. 110-121. (In Russian).

Baturo A. Cursus Honorum: Personal Background, Careers and Experience of Political Leaders in Democracy and Dictatorship. New Data and Analyses. Politics and Governance, 2016, 4 (2), pp. 138-157. https://doi. org/10.17645/pag.v4i2.602.

Best H., Cromwell V., Hausmann C., Rush M. The Transformation of Legislative Elites: The Cases of Britain and Germany since the 1860s. Journal of Legislative Studies, 2001, 7 (3), pp. 65-91. https://doi.org/10.1080/714003883.

Bianco W.T. Last Post for “The Greatest Generation": The Policy Implications of the Decline of Military Experience in the U.S. Congress. Legislative Studies Quarterly, 2005, 30 (1), pp. 85-102. https://doi.org/10.3162/036298005X201464.

Black G.S. (1972) A Theory of Political Ambition: Career Choices and the Role of Structural Incentives. American Political Science Review, 1972, 66 (1), pp. 144- 159. https://doi.org/10.2307/1959283.

Bogatyreva L.V. (2012) Mehanizmy rekrutirovanija glav regional'nyh zakonodatel'nyh sobranij (na primere regionov CFO) [Recruitment mechanisms for heads of regional legislative assemblies (on the example of the regions of the Central Federal District)]. Politicheskaja nauka [Political Science], 2012, 1, pp. 175-189. (In Russian).

Boubakri N., Guedhami O., Mishra D., Saffar W. Political Connections and the Cost of Equity Capital, 2008. Available at: http://citeseerx.ist.psu.edu/viewdoc/ download?doi=10.1 1.175.6368\&rep=rep1\&type=pdf (accessed: 16.04.2017).

Burenkova Je.Je. Transformacii obshhestva i vnutrennie harakteristiki jelitnyh grupp. Ob izuchenii jelitnyh grupp [The transformation of society and the internal characteristics of elite groups. On the study of elite groups]. Mir Rossii [World of Russia], 1995, 3-4, pp. 3-24. (In Russian).

Bystrova A.S. (2017) Vlijanie social'nogo konteksta na postroenie kar'ernyh traektorij: kar'ery predstavitelej razlichnyh politicheskih pokolenij regional'nyh administrativnyh jelit Rossijskoj Federacii [The influence of the social context on the construction of career paths: careers of representatives of various political generations of the regional administrative elites of the Russian Federation]. In: Duka A.V. (ed.) Vlast' $i$ jelity [Power and Elites], t. 4. St. Petersburg: Intersocis, 2017|: 170-203. (In Russian).

Bystrova A.S., Daugavet A.B., Duka A.V., Tev D.B. Regional'nye vlastnye gruppy: osnovnye social'no-strukturnye harakteristiki i rol' $\mathrm{v}$ razvitii sovremennogo rossijskogo obshhestva [Regional power groups: basic socio-structural characteristics 
and role in the development of modern Russian society]. In: Duka A.V. (ed.) Vlast' $i$ jelity [Power and Elites], vol. 4. SPb.: Intersocis, 2017, pp. 147-169. (In Russian).

Bystrova A., Duka A., Kolesnik N., Nevskij A., Tev D. Rossijskie regional'nye jelity: innovacionnyj potencial v kontekste globalizacii [Russian regional elites: innovative potential in the context of globalization]. In: Eliseeva I.I. (ed.) Globalizacija $v$ rossijskom obshhestve: sb. nauch. trudov [Globalization in Russian society: a collection of scientific papers]. SPb.: Nestor-Istorija, 2008, pp. 99-243. (In Russian).

Carnes N. Does the Numerical Underrepresentation of the Working Class in Congress Matter? Legislative Studies Quarterly, 2012, 37 (1), pp. 5-34. https://doi. org/10.2307/41719830.

Carnes N., Lupu N. Rethinking the Comparative Perspective on Class and Representation: Evidence from Latin America. American Journal of Political Science, 2015, 59 (1), pp. 1-18. https://doi.org/10.1111/ajps.12112.

Chaisty P. The Preponderance and Effects of Sectoral Ties in the State Duma. EuropeAsia Studies, 2013, 65 (4), pp. 717-736. https://doi.org/10.1080/09668136.2013.767605.

Chen C.J.P., Li Z., Su X., Sun Z. Rent-seeking incentives, corporate political connections, and the control structure of private firms: Chinese evidence. Journal of Corporate Finance, 2011, 17 (2), pp. 229-243. https://doi.org/10.1016/j. jcorpfin.2010.09.009.

Cotta M., Verzichelli L. Paths of Institutional Development and Elite Transformations. In: Cotta M., Best H. (eds.) Democratic Representation in Europe: Diversity, Change, and Convergence. Oxford: Oxford University Press, 2007, pp. 417-473.

Derge D.R. The Lawyer as Decision-Maker in the American State Legislature, Journal of Politics, 1959, 21 (3), pp. 408-433. https://doi.org/10.2307/2127322.

Duka A.V. (ed.) Regional'nye jelity Severo-Zapada Rossii: politicheskie i jekonomicheskie orientacii [Regional elites of Russia's North-West: political and economic orientations]. St. Petersburg: Aletejja, 2001. 352 p. (In Russian).

Duka A.V. K voprosu o militokratii: siloviki v regional'nyh vlastnyh jelitah [On the issue of militocracy: siloviki in regional power elites]. In: Duka A.V. (ed.) Vlastnye struktury i gruppy dominirovanija: Materialy desjatogo Vserossijskogo seminara «Sociologicheskie problemy vlasti v uslovijah rossijskoj transformacii» [Power structures and domination groups: Materials of the tenth All-Russian seminar "Sociological problems of power institutions under conditions of Russian transformation”]. St. Petersburg: Intersocis, 2012, pp. 94-20. (In Russian).

Dyer J.A. Do Lawyers Vote Differently? A Study of Voting on No-Fault Insurance. Journal of Politics, 1976, 38 (2), pp. 452-456.

Edinger M. Elite Formation and Democratic Elitism in Central and Eastern Europe: A Comparative Analysis'. In: Best H., Higley J. (eds.) Democratic Elitism: New Theoretical and Comparative Perspectives. Leiden: Brill, 2010, pp. 129-151.

Edinger L., Searing D. Social Background in Elite Analysis: A Methodological Inquiry. American Political Science Review, 1967, 61 (2), pp. 428-445. https://doi. org/10.2307/1953255. 
Erikson R.S. The Advantage of Incumbency in Congressional Elections. Polity, 1971, 3 (3), pp. 395-405.

Faccio M. Differences between Politically Connected and Nonconnected Firms: A Cross-Country Analysis. Financial Management, 2010, 39 (3), pp. 905-928. https:// doi.org/10.1111/j.1755-053X.2010.01099.x.

Frye T., Reuter O.J., Szakonyi D. Political Machines at Work Voter Mobilization and Electoral Subversion in the Workplace. World Politics, 2014, 66 (2), pp. 195-228. https://doi.org/10.1017/S004388711400001X.

Gaman-Golutvina O.V. Politicheskie jelity Rossii. Vehi istoricheskoj jevoljucii [The political elites of Russia. Milestones of historical evolution]. Moscow: ROSSPEN, 2006. 446 p. (In Russian).

Gehlbach S., Sonin K., Zhuravskaya E. Businessman Candidates. American Journal of Political Science, 2010, 54 (3), pp. 718-736. https://doi.org/10.1111/j.1540-5907.2010.00456.x.

Goldman E., Rocholl J., So J. Do Politically Connected Boards Affect Firm Value? Review of Financial Studies, 2009, 22 (6), pp. 2331-2360. https://doi.org/10.1093/rfs/hhn088.

Golosov G.V. Legislative Turnover and Executive Control in Russia's Regions (2003-2014). Europe-Asia Studies, 2017, 69 (4), pp. 553-570. https://doi.org/10.108 0/09668136.2017.1337871.

Golosov G.V. Machine Politics: The Concept and Its Implications for Post-Soviet Studies. Demokratizatsiya. The Journal of Post-Soviet Democratization, 2013, 21 (4), pp. 459-480.

Golosov G.V. The Regional Roots of Electoral Authoritarianism in Russia. EuropeAsia Studies, 2011, 63 (4), pp. 623-639. https://doi.org/10.1080/09668136.2011.566427.

Green J.J., Schmidhauser J.R., Berg L.L., Brady D. Lawyers in Congress: A New Look at Some Old Assumptions. Western Political Quarterly, 1973, 26 (3), pp. 440-452. https://doi.org/10.1177/106591297302600304.

Grigor'eva M.V. Uchastie regional'nyh i municipal'nyh deputatov v vyborah zakonodatel'nyh sobranij sub\#ektov RF [Participation of regional and municipal deputies in the election of legislative assemblies of constituent entities of the Russian Federation]. Vestnik Permskogo universiteta. Serija: Politologija [Bulletin of Perm University. Series: Political Science], 2012, 3, pp. 13-29. (In Russian).

Gudkov L. Pererozhdenie kommunisticheskoj nomenklatury [The rebirth of the communist nomenclature]. In: Zubov A., Strada V. (ed.) Rossija na rubezhe vekov [Russia at the turn of the century]. 1991-2011. Moscow: Rossijskaja politicheskaja jenciklopedija (ROSSPJeN), 2011, pp. 116-133. (In Russian).

Hall R.L., van Houweling R.P. Avarice and Ambition in Congress: Representatives' Decisions to Run or Retire from the U.S. House. American Political Science Review, 1995, 89 (1), pp. 121-136. https://doi. org/10.2307/2083079.

Hansen E.R., Carnes N., Gray V. What Happens When Insurers Make Insurance Laws? State Legislative Agendas and the Occupational Makeup of Government. State Politics \& Policy Quarterly, 2019, 19 (2), pp. 155-179. https://doi.org/10.1177/1532440018813013.

Herrick R., Moore M.K Political Ambition's Effect on Legislative Behavior: Schlesinger's Typology Reconsidered and Revised. Journal of Politics, 1993, 55 (3), pp. 765-76. https://doi.org/10.2307/2132000. 
Hutcheson D.S. Party Finance in Russia. East European Politics, 2012, 28 (3), pp. 267-282. https://doi.org/10.1080/21599165.2012.689978.

Ilonszki G., Edinger M. MPs in Post-Communist and Post-Soviet Nations: A Parliamentary Elite in the Making. Journal of Legislative Studies, 2007, 13 (1), pp. 142-163. https://doi.org/10.1080/13572330601165436.

Kerbo H.R., Fave L.R.D. The Empirical Side of the Power Elite Debate: an Assessment and Critique of Recent Research. Sociological Quarterly, 1979, 20 (1), pp. 5-22. https://doi.org/10.1111/j.1533-8525.1979.tb02181.x.

Kim C.L., Patterson S.C. Parliamentary Elite Integration in Six Nations. Comparative Politics, 1988, 20 (4), pp. 379-399. https://doi.org/10.2307/421935.

Korgunjuk Ju.G. Finansirovanie partij v postsovetskoj Rossii: mezhdu biznesom i vlast'ju [Party Financing in Post-Soviet Russia: Between Business and Government]. Politija: Analiz. Hronika. Prognoz (Zhurnal politicheskoj filosofii i sociologii politiki) [Politeia. The Journal of Political Theory, Political Philosophy and Sociology of Politics], 2010, 3-4 (58-59), pp. 87-120. (In Russian).

Kryshtanovskaja O. Anatomija rossijskoj jelity [Anatomy of the Russian elite]. Moscow: Zaharov, 2004. 384 p. (In Russian).

Kryshtanovskaja O. Transformacija staroj nomenklatury v novuju rossijskuju jelitu [Transformation of the old nomenclature into the new Russian elite]. Obshhestvennye nauki i sovremennost' [Social Sciences and Contemporary World], 1995, 1, pp. 51-65. (In Russian).

Kryshtanovskaja O. Jelita v setjah: novye formy obratnoj svjazi v cifrovuju jepohu [Network Elite: New Forms of Feedback in the Digital Age]. Cifrovaja sociologija [Digital sociology], 2019, № 2 (2), pp. 4-11. https://doi.org/10.26425/2658347X-2019-2-4-11. (In Russian).

Kukolev I.V. Transformacija politicheskih jelit v Rossii [The transformation of political elites in Russia]. Obshhestvennye nauki i sovremennost' [Social Sciences and Contemporary World], 1997, 4, pp. 82-91. (In Russian).

Latypov R.F. Jevoljucija politiko-administrativnyh jelit v postsovetskoj Rossii: kross-regional'nyj analiz [The evolution of political and administrative elites in postSoviet Russia: cross-regional analysis]. Sociologija vlasti [Sociology of Power], 2009, 6, pp. 110-118. (In Russian).

Lawless J.L. Becoming a Candidate: Political Ambition and the Decision to Run for Office. Cambridge: Cambridge University Press, 2012. 302 p.

Makarenko B.I. The Post-Soviet Party of Power: United Russia in Comparative Context. Russian Social Science Review, 2012, 53 (4), pp. 27-56. https://doi.org/10.1 080/10611428.2012.11065482.

Matland R.E., Studlar D.T. Determinants of Legislative Turnover: A CrossNational Analysis. British Journal of Political Science, 2004, 34 (1), pp. 87-108. https:// doi.org/10.1017/S000712340300036X.

Matthews D.R. United States Senators and the Class Structure. Public Opinion Quarterly, 1954, 18 (1), pp. 5-22. https://doi.org/https://doi.org/10.1086/266482. 
Matthews D.R. Legislative Recruitment and Legislative Careers. Legislative Studies Quarterly, 1984, 9 (4), pp. 547-585. https://doi.org/10.2307/439635

Medvedev Ju.S. Professional'nyj status kak faktor uspeha na regional'nyh vyborah [Professional status as a factor of success in regional elections]. Politija: Analiz. Hronika. Prognoz (Zhurnal politicheskoj filosofii i sociologii politiki) [Politeia. The Journal of Political Theory, Political Philosophy and Sociology of Politics], 2010, 2 (57), pp.75-90. (In Russian).

Nicholls K. The Dynamics of National Executive Service. Ambition Theory and the Careers of Presidential Cabinet Members. Western Political Quarterly, 1991, 44 (1), pp. 149-172. https://doi.org/10.2307/448752.

Norris P., Lovenduski J. Political Recruitment: Gender, race and class in the British parliament. Cambridge: Cambridge University Press, 1995. 320 p.

Öhberg, Patrik. Ambitious Politicians. The Implications of Career Ambition in Representative Democracy. Lawrence: University Press of Kansas, 2017. 224 p.

Pihoja R.G Kak vlast' obmenjali na sobstvennost' [How power was exchanged for property]. Sociologija vlasti [Sociology of Power], 2011, 11, pp. 5-11. (In Russian).

Ponedelkov A.V. Politicheskaja jelita: genezis i problemy ee stanovlenija v Rossii [Political elite: genesis and problems of its formation in Russia]. Rostov-na-Donu: Izd-vo SKNC VSh., 1995. 208 p. (In Russian).

Putnam R.D. The Comparative Study of Political Elites. Englewood Cliffs, N.J.: Prentice-Hall, 1976. 246 p.

Regional'nyye elity Severo-Zapada Rossii: politicheskiye i ekonomicheskiye oriyentatsii [Regional elites of the North-West of Russia: political and economic orientations]. Ed. by. A.V. Duka. St. Petersburg: Aleteyya, 2001. 352 p.

Reuter O.J., Turovsky R. Dominant party rule and legislative leadership in authoritarian regimes. Party Politics, 2014, 20 (5), pp. 663-674. https://doi. org/10.1177/1354068812448689.

Roberts S.P. United Russia and the Dominant-Party Framework: Understanding the Russian Party of Power in Comparative Perspective. East European Politics, 2012, 28 (3), pp. 225-240. https://doi.org/10.1080/21599165.2012.684754.

Safronov V.V. Konsolidacija avtoritarizma ili demokratizacija: podderzhka putinskogo rezhima jelitoj S.-Peterburga [The consolidation of authoritarianism or democratization: support for the Putin regime by the elite of St. Petersburg]. In: Duka A.V., Eliseeva I.I. (ed.) Uslovija i vozmozhnosti konsolidacii rossijskogo obshhestva: Sbornik nauchnyh trudov SI RAN [Conditions and Opportunities for the Consolidation of Russian Society: Collection of scientific papers of the SI RAS]. St. Petersburg: Nestor-Istorija, 2010, pp. 30-110. (In Russian).

Sakwa R. Party and Power: Between Representation and Mobilisation in Contemporary Russia. East European Politics, 2012, 28 (3), pp. 310-327. https://doi. org/10.1080/21599165.2012.683784.

Schlesinger J.A. Ambition and Politics. Political Careers in the United States. Chicago: Rand McNally and Company, 1966. 226 p. 
Seleznev A.V., Rogozar'-Kolpakova I.I., Filistovich E.S., Trofimova V.V., Dobrynina E.P., Strelec I.Je. Rossijskaja politicheskaja jelita: analiz s tochki zrenija koncepcii chelovecheskogo kapitala [Russian political elite: analysis from the point of view of the concept of human capital]. Politicheskie issledovanija [Political Studies], 2010, 4, pp. 90-106. (In Russian).

Shabad G., Slomczynski K.M. The Emergence of Career Politicians in PostCommunist Democracies: Poland and the Czech Republic. Legislative Studies Quarterly, 2002, 27 (3), pp. 333-359. https://doi.org/10.2307/3598567.

Shirikov A.S. Anatomija bezdejstvija: politicheskie instituty $i$ konflikty $v$ bjudzhetnom processe regionov Rossii [Anatomy of Inaction: Political Institutions and Conflicts in the Budget Process of Russian Regions]. St. Petersburg: Izdatel'stvo Evropejskogo universiteta v Sankt-Peterburge, 2010. 276 p. (In Russian).

Slepcov N.S., Kukolev I.V., Ryskova T.M. Novaja legitimnost' regional'nyh liderov [The new legitimacy of regional leaders]. Sociologija vlasti [Sociology of Power], 1997, 3, pp. 5-23. (In Russian).

Slider D. How United is United Russia? Regional Sources of Intra-party Conflict. Journal of Communist Studies and Transition Politics, 2010, 26 (2), pp. 257-275. https://doi.org/10.1080/13523271003712617.

Szakonyi D. Businesspeople in Elected Office: Identifying Private Benefits from Firm-Level Returns. American Political Science Review, 2018, 112 (2), pp. 322-338. https://doi.org/10.1017/S0003055417000600.

Szakonyi D. Private Sector Policymaking: Business Background and Politicians' Behavior in Office, 2017. Available at: https://papers.ssrn.com/sol3/papers. cfm?abstract_id=2844901 (accessed: 22.12.2017).

Szakonyi D. Renting Elected Office: Why Businesspeople Become Politicians in Russia. Submitted in partial fulfillment of the requirements for the degree of Doctor of Philosophy in the Graduate School of Arts and Sciences. Columbia University, 2016. Available at: https://academiccommons.columbia.edu (accessed: 17.12.2014).

The Economist. Planet Plutocrat: Our Crony-Capitalism Index, 2014. Available at: http://www. economist.com/news/international/21599041-countries-where-politicallyconnectedbusinessmen-are-most-likely-prosper-planet (accessed: 17.12.2014).

Vercesi M. Approaches and lessons in political career research: Babel or pieces of patchwork? Revista Española de Ciencia Política, 2018, 48, pp. 183-206. https:// doi.org/10.21308/recp.48.07.

Wilson K. Party Finance in Russia: Has the 2001 Law «On Political Parties» Made a Difference? Europe-Asia Studies, 2007, 59 (7), pp. 1089-1113. https://doi. org/10.1080/09668130701607094

Witko C., Friedman S. (2008) Business Backgrounds and Congressional Behavior. Congress \& the Presidency, 2008, 35 (1), pp. 71-86. https://doi. org/10.1080/07343460809507652. 